Article

\title{
Smartphone Use and Academic Performance of University Students: A Mediation and Moderation Analysis
}

\author{
Rizwan Raheem Ahmed ${ }^{1, *(\mathbb{D})}$, Faryal Salman ${ }^{2}$, Shahab Alam Malik ${ }^{1}$, Dalia Streimikiene ${ }^{3, *(\mathbb{D} \text {, }}$ \\ Riaz Hussain Soomro ${ }^{2}$ D and Munwar Hussain Pahi ${ }^{4}$ \\ 1 Faculty of Management Sciences, Indus University, Block-17, Gulshan, Karachi 75300, Pakistan; \\ shahabmaliks@gmail.com \\ 2 Institute of Health Management, Dow University of Health Sciences, Mission Road, Karachi 74200, Pakistan; \\ faryal.salman@duhs.edu.pk (F.S.); riaz.soomro@duhs.edu.pk (R.H.S.) \\ 3 Institute of Sport Science and Innovations, Lithuanian Sports University, Sporto str. 6, \\ Kaunas 44221, Lithuania \\ 4 College of Business Management, PAF-KIET University, Korangi Creek, Karachi 75190, Pakistan; \\ hussainpahi@gmail.com \\ * Correspondence: rizwanraheemahmed@gmail.com (R.R.A.); dalia.streimikiene@lei.lt (D.S.)
}

Received: 3 December 2019; Accepted: 1 January 2020; Published: 6 January 2020

\begin{abstract}
The purpose of the undertaken study is to examine the influence of smartphones on the performance of university students in Pakistan. This paper also investigates the functions of a smartphone as exogenous predictors such as smartphone applications, multimedia messaging service (MMS), short message service (SMS), warp-speed processing, and entertainment on the academic performance of a student. This paper also addresses the impact of electronic word of mouth (eWOM) and attitude as mediating variables between exogenous and endogenous variables. Finally, we incorporated technology and addiction as moderating variables between independent variables and the outcome variable to measure the influence of moderating variables. We have taken 684 responses from seven universities in Pakistan and employed the SEM-based multivariate approach for the analysis of the data. The findings of this paper demonstrate that smartphone functions have a significant influence on students' academic performance, and moderating and mediating variables also have a significant influence on exogenous and endogenous variables. The practical implications have provided a guideline for university teachers, parents, and decision-makers of how a smartphone could be used to improve student academic performance inside and outside university campuses.
\end{abstract}

Keywords: smartphone usage; academic performance; university students; SEM-based approach; mediation and moderation

\section{Introduction}

The rising upsurge in the use of cellphones has paved the way for the 'mobile revolution' whereby smartphones hold a center point in a consumer's life as they spend significant time using them. This proximity with smartphones supersedes time spent and relations with all other portable electronic devices. Consumers fear that smartphones have become indispensable as they are constantly hooked to their gadgets not only for online activities but also for monitoring and controlling a plethora of their daily activities. As per the statistics shared by Deloitte in the Global Mobile Consumer Survey, the US edition [1], mobile phone penetration in the US alone is $85 \%$ among the baby boomers and about $90 \%$ among the millennial. The proliferated use of smartphones poses new challenges for higher education institutes along with the detrimental effects these devices have on the overall academic performance of 
university students [2]. Moreover, this $24 / 7$ 'online connectivity' phenomenon is increasingly becoming a source of distraction and distress among the younger population as lower exam scores were found, which was correlated to the excessive use of portable devices such as cell phones [3,4].

Smartphones have become a popular medium of social as well as academic connection. Proponents of smartphone usage in higher education institutes assert that students communicate with each other through their cellphones to exchange notes, lectures, and assignments and for productive academic discussions [5]. Prolific literature is available that empirically proves the negative impact of excessive smartphone usage on student academic performance in universities such as Mendoza et al. [6], Giunchiglia et al. [7], Duke and Montag [8], Yang et al. [9], Nayak [10], and Ali et al. [11]. According to Han and Yi [4], Kibona and Mgaya [12], and Froese et al. [13], the high level of addiction to the smartphone negatively influences the student's academic performance. Thus, this level of addiction causes several concerns on whether the usage of smartphone elevates or deteriorates student academic performance. Several research studies have been carried out on new digital technologies and smartphone applications that enhance the effectiveness of the overall learning prospects of higher education institutions. These research studies demonstrate that smartphone applications and digital technologies have enhanced the teaching and learning capabilities of teachers and students [14-18]. On the other hand, several studies have advocated the positive influence of smartphone applications and new technologies on the academic performance of university students [19-26]. Thus, there is no conclusive evidence that the smartphone has really increased or decreased student academic performance, therefore, there is a dire need to reexamine the impact of the smartphone on the academic performance of university students. Hence, the undertaken study was carried out to investigate university students' academic performance with the maximum functions of a smartphone.

Hence, keeping the view of these effects of the smartphone on the daily lives of university students, this study is an attempt to ascertain an association amid students' academic performance in universities, and smartphone usage among university students in Pakistan. The significance of the undertaken study lies in several factors. Through empirical evidence, the authors investigate the functions of a smartphone as exogenous predictors such as smartphone applications, multimedia messaging service (MMS), and short message service (SMS), warp-speed processing, and entertainment on academic performance of a student. At the same time, this paper also addresses the impact of electronic word of mouth (eWOM) and attitude as mediating variables between exogenous and endogenous variables in a relationship between functions of a smartphone and student academic performance. The study also evaluates the impact of technology and addiction as a moderator between the functions of smartphone and student performance. We used the SEM-based multivariate approach in which we employed exploratory factor analysis, confirmatory factor analysis, and conditional process modeling. Thus, this kind of detailed study is carried out for the first time in Pakistan regarding smartphone usage amongst university students which provides new dimensions to future researchers, parents, teachers, smartphone marketers, and policymakers to comprehend the real issues and come up with corrective strategies to channelize the best use of a smartphone.

The rest of the paper is organized as follows. Section 2 discusses the relevant previous literature, Section 3 elaborates the Material and Methods, Section 4 contains results and findings of the undertaken study, Section 5 deals with the discussion, and Section 6 comprises the conclusion followed by the theoretical and managerial implication of the undertaken study.

\section{Review of Previous Literature}

Mendoza et al. [6] conducted an interesting experiment where participants were divided into two groups and attended a short lecture under different cellphone conditions (with/without smartphones). In this paper, the authors suggested that excessive use of smartphones is a cause of distraction and hampers learning during classroom lectures. The groups that were allowed to keep their smartphones kept on receiving distracting messages. Their attention span was much shorter as compared to the group without access to smartphones. The findings of the study establish the causality between 
technology and learning and also suggest that the academic performance of students can be made more effective by limiting the use of technology during class lectures.

Giunchiglia et al. [7] monitored the students' time, which was spent on social media using their smartphones and its effect on student academic performance in universities. The respondents were encouraged to maintain a logbook to keep track of their interaction with smartphones and the usage of social media. The finding of the study suggested that excessive use of smartphones led to 'addictiveness' that negatively influenced student academic performance in universities. In a similar research study, Duke and Montag [8] studied the impact of smartphone addiction in the context of overall smartness, wellbeing, and productivity of the millennial. They established a link between the work-related usage of smartphones and self-rated productivity. It was found that too much use of smartphones causes 'techno stress' which impacts mental health and ultimately leads to declined work-related performance.

Yang et al. [9] explored the 'problematic use of smartphones' (PSU) among university students in China. The authors studied the association amid PSU, academic procrastination, and academic anxiety. The findings of the study proposed an affirmative relation amid PSU, academic anxiety, and deferment. The authors also suggested that students could control the excessive use of smartphones through exercising self-regulation. Nayak [10] studied the influence of smartphones on student academic performance in universities of India. The author focused on gender differences and found that although female students used more smartphones as compared to their male counterparts, the males neglected their work, felt anxious, and had less self-control due to smartphone addiction and consequently fared poorly in their studies as compared to female students.

According to Jacobsen and Forste [27], smartphone usage created the negative impact of texting and calling on a self-reported Grade Point Average (GPA) for university students' academic performance in the case of the United States. On the contrary, Hong et al. [28] concluded the positive association between calling and texting on academic performance in perspective of Taiwan's female university students. In the same vein, Lepp et al. [29] demonstrated that students who use fewer smartphones show better academic performance than those who use more smartphones. Similarly, Wood et al. [30], Rosen et al. [31], Kirschner and Karpinski [32], Karpinski et al. [33], and Junco [34] demonstrated the negative association amid the use of a smartphone and student academic performance in universities. Several research studies have been carried out on new digital technologies and smartphone applications that enhance the effectiveness of the overall learning prospects of higher education institutions. These research studies demonstrate that smartphone applications and digital technologies have enhanced the teaching and learning capabilities of teachers and students [14-18].

García-Martínez et al. [14] took a detailed systemic review of 16 research studies, which were published in the Web of Science and Scopus journals. They reviewed these papers and concluded that in general, smartphone applications have a positive influence on the learning capacities of university students. Similarly, several research studies have advocated the positive influence of smartphone applications and new technologies on the academic performance of university students [19-26]. However, few research studies have concluded a negative influence of smartphone usage that hampers the academic performance of university students such as Ali et al. [11], Mendoza et al. [6], Giunchiglia et al. [7], Duke and Montag [8], Yang et al. [9], and Nayak [10]. According to Han and Yi [4], Kibona and Mgaya [12], and Froese et al. [13], the high level of addiction to the smartphone negatively influences student academic performance.

Thus, based on the previous literature, it is occluded that there are inconclusive results regarding smartphone use and student academic performance in universities, therefore, there is a strong need to investigate this relationship with more variables and with greater scope. Hence, keeping a view of these effects of the smartphone on student academic performance in universities, this study is an attempt to ascertain an association between student academic performance in universities and smartphone usage in Pakistan. According to Ahmed et al. [35], recent statistics exhibited that $60 \%$ of the Pakistani population comprises of youth who are heavy users of smartphones, henceforth this study primarily 
focuses on university students. In this scenario, the importance of the undertaken study has more practical implications in the perspective of student academic performance in Pakistani universities.

\subsection{Conceptual Framework and Hypotheses Formation}

\subsubsection{Direct Hypothesized Relationship}

A framework of relationship is developed to understand the direct hypothesized relationship between the exogenous variables such as multimedia messaging service (MMS), short message service (SMS), mobile applications, warp-speed processing (WSP), and entertainment on student academic performance in universities.

\section{Multimedia Messaging Service (MMS) and Student Performance}

Multimedia messaging service is an advanced version of text messages whereby the sender can send audio, video, images, clips, or any multimedia content through cellphones in addition to the text messages. Numerous research studies have been carried out on the influence of MMS on student academic performance [18,31,34]. Junco [34] asserted that students who frequently share videos and pictures through text messaging during class lectures face learning difficulties, hampering performance. Wood et al. [30] and Rosen et al. [31] asserted that technology induces interruptions in memory recall due to the continuous infiltration of MMS during lectures. Authors proposed that such messages, if used with high-frequency, cause interruptions in learning and thus, directly impact academic learning. Multimedia messaging service empowered students and consumers to use motion media efficiently. For this purpose, high tech smartphones and portable computers are being used for real-time information exchange which could be transferred anywhere at any minimal period $[18,36]$. Thus, with the introduction of new functions of multimedia messaging service (MMS), traditional media such as newspapers, magazines, billboards, and TV have faced a real challenge, and students' performance has become very effective in their studies and real-live events [21,25,37]. Due to the multimedia channels, students use millions of academic websites, YouTube, and customized educational portals for their academic requirements. [38,39]. These new multimedia messaging service (MMS) channels have also reduced the cost of educational material phenomenally for university students. It is therefore hypothesized that:

Hypothesis 1. Multimedia messaging service (MMS) is positively associated with students' academic performance.

Short Message Service (SMS) and Student Performance

SMS is an abbreviation of short message service sent through cellphones or smartphones. The concept of text messages was first introduced in the 1980s, however, they became a popular medium of communication after the introduction of cellphones $[19,40,41]$. Although SMS is restricted by the amount of text, characters, and number that can be sent in one message, they are still largely used by the millennial. According to Tindell and Bohlander [2], many students continue using text service in class while attending lectures and this multitasking affects academic learning. Rosen et al. [31] also suggested students tend to continuously check their cellphones for messages and tend to respond the moment they arrive. This distracts their mind and poses difficulty in retaining a lecture. The enormous increase of smartphone use unveiled another quick medium of communication to consumers and university students [42-45]. Short message service (SMS) is the most used medium, which is more prolific than traditional media for consumers and university students [46-49]. SMS is a more practical, viable, and cost-effective medium than traditional media [46]. University students use the short message service (SMS) for their day-to-day matters that are very linked with their academic performance [47-50]. Moreover, the short message service (SMS) medium could be used without a time bar which makes it a more profound and useful medium for the students' academic performance [51-53]. It is therefore hypothesized that: 
Hypothesis 2. Short message service is (SMS) negatively associated with students' academic performance.

Mobile Application (Mobile Apps) and Student Performance

Smartphones are equipped with different types of applications that are commonly used during in-class learning by the students. As reported by Woodcock et al. [40], these applications are effective learning tools that enhance students' productivity and academic performance. Similarly, Kumar [54] concluded that the use of smartphone applications facilitates student learning performance and timely completion of assignments, projects, and tasks. This was also reinforced by the work of Mtega et al. [55], who identified that smartphone apps are used to share academic resources among friends and thus, helps timely completion of their works. The mobile phone applications have brought a tremendous revolution to consumers and students in which students can go directly to the targeted and customized service $[21,24,56-58]$. Software related to smartphone applications can automatically be downloaded from host companies of smartphone manufacturers [59]. These smartphone applications are made in house or through outsourcing for the educational purposes for primary and tertiary education $[59,60]$. University students can use these applications for their specific educational and entertainment purposes [60-62]. It is estimated that more than one application is used in one smartphone, and approximately 55 billion USD is spent on smartphone applications annually [61]. It is therefore hypothesized:

Hypothesis 3. Mobile applications are positively associated with students' academic performance.

Warp-Speed Processing (WSP) and Student Performance

Warp-speed processing determines the speed of cellphones and helps improve the functions of smartphones. The fifth-generation era, or $5 \mathrm{G}$ as known commonly, will have a cogent influence on the functioning of smartphones in terms of speed, accessibility, and connectivity. As suggested by Han and Yi [4], students using smartphone-based communication were likely to display better academic performance. Chou and Liu [63] worked on the technology-mediated virtual learning environment and its impact on students learning. The authors found that technology positively enhances student learning and performance. Warp-speed processing is imperative for rich media such as audio and video $[16,18,22,63,64]$. Internet speed is also paramount for download speed; the bandwidth is responsible for the higher download speed. Academic material such as videos, tutorials, software, eBooks, and other online material are dependent on the speed of the Internet $[64,65]$. Thus, it is proven that the speed of processors and warp-speed processing is the most vital for the student material that is downloaded from the websites; hence, warp-speed processing is a significant factor that can enhance student academic performance $[42,61,64-66]$. It is thus hypothesized that:

Hypothesis 4. Warp-speed processing (WSP) is positively associated with students' academic performance.

\section{Entertainment and Student Performance}

Smartphones are identified as a major source of entertainment for the younger generation. In recent research carried out by Giunchiglia et al. [7], it was found that smartphones, due to their pervasiveness, damage students' career and thus, social media is negatively correlated to academic performance. Junco [34] maintained that using smartphone apps for entertainment while doing assignments or during lectures taxes the cognitive learning ability of students and thus negatively correlates with their performance $[67,68]$. Social media provides enormous opportunities for entertainment for university students; social media is the connectivity between the communities $[69,70]$. Thus, this connectivity can affect either side of student academic performance [70,71]. YouTube and other video social networks are also beneficial to university students for academic performance, but again it depends on the usage of these networks [12,42]. Movies, games, and other activities are healthy if they are used within the controlled framework; thus, teachers and parents' responsibility also plays a vital role to educate 
students at their primary and younger stages [71-73]. The overall cost and benefit analysis of these media exhibited that the minuses are more dominant as compared to the pluses; hence the entertainment is the two-edged sword, which can hamper university students' academic performance [72,73]. It is, therefore, hypothesized as follows:

Hypothesis 5. Entertainment is negatively associated with students' academic performance.

\subsubsection{Indirect Hypothesized Relationship (Mediation)}

The current study takes into account the impact of electronic word of mouth (eWOM) and attitude as mediating variables between exogenous and endogenous variables.

\section{Electronic Word of Mouth (eWOM) as a Mediator}

Interpersonal communication skills are strongly influenced by social media [74,75]. Thus, the Electronic word of mouth (eWOM) is a kind of information exchange between receiver and sender using electronic and digital media [76,77]. In their works, Hennig-Thurau et al. [78] identified online travel agencies, online video games, music, and video streaming, online shops, social networks, and whistleblower websites as the commonly known media for eWOM communication. The younger generation finds instant messaging (IM) highly attractive because they are closely connected to their friends and get an immediate response. Applications are gaining much popularity among young users because of their creative and novel ways to communicate with friends and colleagues through contact information exchange, photo/video sharing, one-to-many messaging, hold-to-talk voice messages, and text messaging. As mentioned in the study conducted by Nayak [10], students who are constantly getting text messages, videos, and audios during their class lectures feel highly distracted, as there is an urgency to instantly reply. These distractions ultimately result in academic loss and poor performance. Several research studies have identified the mediating role of eWOM in making various decisions. Ellison et al. [79], Herr et al. [80], and Vivilaite et al. [81] found that students are connected through social media not only for entertainment, but also for academic purpose. Virtual groups are formed to identify groups of common interests and common class schedules [82,83]. These online communities post negative and positive reviews/comments related to academic affairs $[84,85]$. Yang and Mutum [86] carried out another important research study on the influence of eWOM on students' academic performance in universities and teachers' and managers' roles. The authors found that eWOM influences the perceived information quality and truthfulness, whilst prospective students select a university based on the information provided $[84,86]$. It is thus hypothesized that:

Hypothesis 6A. Electronic word of mouth (eWOM) is a significant and positive mediator between multimedia messaging service (MMS) and students' academic performance.

Hypothesis 6B. Electronic word of mouth (eWOM) is a significant and positive mediator between short message service (SMS) and students' academic performance.

Hypothesis 6C. Electronic word of mouth (eWOM) is a significant and positive mediator between mobile applications and students' academic performance.

Hypothesis 6D. Electronic word of mouth (eWOM) is a significant and positive mediator between warp-speed processing (WSP) and students' academic performance.

Hypothesis 6E. Electronic word of mouth (eWOM) is a significant and positive mediator between entertainment and students' academic performance. 
Attitude as a Mediator

We examined the previous literature regarding university students' usage of smartphones and their academic performance [12,41,42]. Students' attitude towards smartphone usage has been studied in previous literature such as $[8,41,87]$. Previous literature showed both positive and negative attitudes towards the use and student academic performance in universities regarding smartphones $[12,41,42,56]$. Zhang and Mao [88] researched the association amid social media entertainment and student academic performance in universities. The author found that an affirmative attitude regarding social media and various digital tools of online connectivity fosters academic learning among students and thus, has a cogent influence on student academic performance in universities $[87,88]$. Similarly, students with a negative attitude towards social media as a channel for academic learning found it as a source of distraction that also hampers their performance. In another study conducted on students of a healthcare institute, the authors found that attitude towards smartphone usage during lectures significantly influenced academic performance [12,56,89]. Various functions of a smartphone can enhance the learning process. It is therefore hypothesized:

Hypothesis 7A. Attitude is a significant and positive mediator between multimedia messaging service (MMS) and students' academic performance.

Hypothesis 7B. Attitude is a significant and positive mediator between short message service (SMS) and students' academic performance.

Hypothesis 7C. Attitude is a significant and positive mediator between mobile applications and students' academic performance.

Hypothesis 7D. Attitude is a significant and positive mediator between warp-speed processing (WSP) and students' academic performance.

Hypothesis 7E. Attitude is a significant and positive mediator between entertainment and students' academic performance.

\subsubsection{Hypothesized Moderating Relationship}

The current study incorporated technology and addiction as moderating variables between independent variables and outcome variable to measure the influence of moderating variables.

\section{Technology as a Moderator}

Advancement in technology has increased the usage of smartphones by students and the general public [35]. According to Chen and Chang [90], and Saroha and Diwan [91], smartphone functions are experiencing drastic and swift remodeling due to the encompassing influence of telecommunication and information technologies. Drastic and swift access to data and information processing has made the smartphone more useful and advanced. Thus, this swiftness of technology has compelled organizations to adopt new and digital means of communication around the globe [92-95]. Millennials are part of the digital generation where technology is deeply infused in their daily life and helps them in multitasking $[34,35]$. In a previous study, it was reported that research and development (R\&D) and knowledge technologies affirmatively impact student grades and intention to complete the task [96]. The proponents of using a smartphone in academic learning argue that information and communication technologies (ICT) fosters students' overall performance, however, as argued by Aljomaa et al. [97], the impact of smartphone use and student academic performance in universities depends on how technology is introduced and handled. Several other studies also substantiated that technology is a potent moderator in the advancement and delivery system that is important for the functions of the latest smartphone tools $[35,61,98]$. It is therefore hypothesized that: 
Hypothesis 8A. Technology is a significant moderator between multimedia messaging service (MMS) and students' academic performance.

Hypothesis 8B. Technology is a significant moderator between short message service (SMS) and students' academic performance.

Hypothesis 8C. Technology is a significant moderator between mobile applications and students' academic performance.

Hypothesis 8D. Technology is a significant moderator between warp-speed processing (WSP) and students' academic performance.

Hypothesis 8E. Technology is a significant moderator between entertainment and students' academic performance.

\section{Addiction as a Moderator}

Although not officially diagnosed as a clinical disorder, neither its direct impact is known but a smartphone is considered to be addictive as it can interfere in our daily lives $[99,100]$. The authors concluded a moderating role amid smartphone addiction, smartphone interruption, and work-related productivity. Similarly, it was found that excessive use of smartphones during studies leads to the addictive tendency among students that subconsciously negatively impacts their academic performance, daily activities, social relationships, and overall physical and mental wellbeing [10,101]. Another study was conducted on the compulsive use of smartphones and it was demonstrated that addiction to smartphones increases mental stress and reduces concentration among students [102-104]. Smartphone addiction plays a moderating role in the association of smartphone functions, and student academic performance in universities $[12,105,106]$. It is therefore hypothesized that:

Hypothesis 9A. Addiction is a significant moderator between multimedia messaging service (MMS) and students' academic performance.

Hypothesis 9B. Addiction is a significant moderator between short message service (SMS) and students' academic performance.

Hypothesis 9C. Addiction is a significant moderator between mobile applications and students' academic performance.

Hypothesis 9D. Addiction is a significant moderator between warp-speed processing (WSP) and students' academic performance.

Hypothesis 9E. Addiction is a significant moderator between entertainment and students' academic performance.

\subsection{Conceptual Model of the Research Study}

Figure 1 is the depiction of the conceptual framework of the undertaken study in which we showed the impact of smartphone function on the academic performance of students. Moreover, we have also shown the influence of mediating variables and moderating variables between exogenous and endogenous variables. 


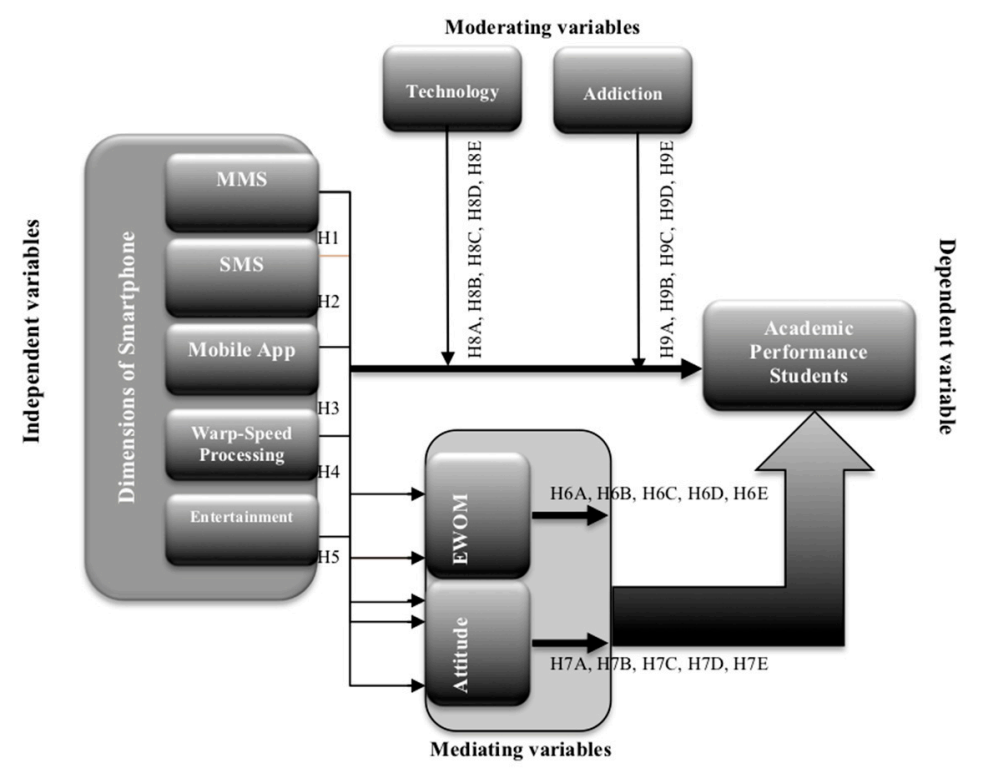

Figure 1. Conceptual model of the research study. Source: Adapted from previous literature [4,35,39, $42,54,84,88,91,106]$.

\section{Material and Methods}

\subsection{Research Design and Selection of Measurement Scales}

The research design of the undertaken study is quantitative and cross-sectional, and data was collected through a modified structured questionnaire. The items of considered variables were adapted from Han and Yi [4], Ahmed et al. [35,106], Chen and Chang [90], Mathwick et al. [39], Çizmeci and Ercan [42], Kumar [54], Goldenberg et al. [84], Zhang and Mao [88], and Saroha and Diwan [91], etc. We used a five-point Likert scale, and responses were collected from ten universities of Karachi, the respondents were enrolled in undergraduate, graduate, postgraduate, and professional degree programs.

\subsection{Sampling Strategy and Sample Size}

We employed a non-probability sampling technique i.e., the purposive technique for collecting the sample data from the selected respondents. We selected those respondents who were using smartphones, and they were well aware of the functionalities of smartphones. Initially, 800 questionnaires were floated to the respondents in which 784 responses were found corrected and completed. However, 16 responses were found incorrect or incomplete.

\subsection{Statistical Techniques for Estimation}

For the analysis purposes, we employed several statistical techniques including exploratory factor analysis (EFA) for the reduction and validation of the considered variables and items; we also used component factor analysis. Descriptive analysis for the basic characteristics of the constructs, further, in EFA we employed total variance extracted, Kaiser-Meyer-Olkin (KMO) and Bartlett's techniques for the suitability, adequacy, and retention of the data [12,106,107]. In our analysis, we also employed a confirmatory factor analysis (CFA) for the analysis of reliabilities and validities. Finally, we used the conditional process modeling for the analysis of direct and indirect (mediation and moderation) relationships between the variables [108-110]. Further elaboration and analysis of these techniques are provided in the next estimation section. 


\subsection{Profile of Respondents}

Researchers included a sample of 784 respondents, however, the questionnaire was forwarded to 800 respondents, thus the response rate is $98.00 \%$, and according to Hair et al. [111], that is considered very good. Table 1 demonstrates the detailed demographic profile of respondents.

Table 1. Respondents' profile.

\begin{tabular}{|c|c|c|c|}
\hline \multicolumn{2}{|c|}{ Demographics } & \multirow{3}{*}{$\begin{array}{c}\text { Frequency } \\
435 \\
349\end{array}$} & \multirow{3}{*}{$\begin{array}{l}\text { Percen } \\
55.48 \% \\
44.52 \%\end{array}$} \\
\hline \multirow{2}{*}{ Gender } & Male & & \\
\hline & Female & & \\
\hline \multirow{2}{*}{ Marital Status } & Single & 671 & $85.59 \%$ \\
\hline & Married & 113 & $14.41 \%$ \\
\hline \multirow{4}{*}{ Age (in years) } & $18-25$ & 321 & $40.94 \%$ \\
\hline & $25-30$ & 273 & $34.82 \%$ \\
\hline & 30-35 & 102 & $13.01 \%$ \\
\hline & More than 35 & 88 & $11.22 \%$ \\
\hline \multirow{4}{*}{ Education (enrolled) } & Under-graduation & 362 & $46.17 \%$ \\
\hline & Graduation & 243 & $30.99 \%$ \\
\hline & Post-Graduation & 115 & $14.67 \%$ \\
\hline & Professional degree & 64 & $8.16 \%$ \\
\hline \multirow{4}{*}{ Experience (in years) } & $0-0$ & 276 & $35.20 \%$ \\
\hline & $1-5$ & 219 & $27.93 \%$ \\
\hline & 5-10 & 188 & $23.98 \%$ \\
\hline & More than 10 & 101 & $12.88 \%$ \\
\hline \multirow{5}{*}{ Income (in PKR 000) } & $0-0$ & 287 & $36.61 \%$ \\
\hline & $10-25$ & 210 & $26.79 \%$ \\
\hline & $25-35$ & 161 & $19.26 \%$ \\
\hline & $35-45$ & 89 & $10.84 \%$ \\
\hline & More than 45 & 52 & $6.51 \%$ \\
\hline \multicolumn{2}{|c|}{ Total-N } & \multicolumn{2}{|c|}{784} \\
\hline
\end{tabular}

\section{Results}

For the results and estimation, researchers employed descriptive analysis, exploratory and confirmatory factor analysis to confirm the hypothesized measured and structured models. Moreover, researchers employed conditional process analysis to ascertain hypothesized mediation, moderation, and direct association between the factors.

\subsection{Descriptive Statistics}

The confirmation of data normality is paramount for SEM modeling, thus, researchers employed descriptive analysis that consists of skewness, standard deviation, mean, and kurtosis [112]. For this purpose, researchers converted all the values into z-score, and then employed the descriptive analysis, which demonstrates that Kurtosis value ranges from -3 to +3 , however, the values of standard deviation and skewness lie between -1.5 to +1.5 (Table 2) which confirmed the normality of the sample data [113].

\subsection{Reliabilities and Validities}

Table 3 demonstrated composite reliabilities and Cronbach's alpha for seven factors, which showed every factor has a value greater than 0.80 , which is well above the threshold value $(>0.60)$ as suggested by Hair et al. [111]. Outcomes of Table 3 further demonstrated that all the items have factor loadings ranging between $0.70-0.90$, which fulfills the criterion of discriminant validities of all the constructs [12]. 
For all the individual constructs, the average variance explained falls greater than 0.60 , which fulfills the convergent validities of considered items and factors [114,115].

Table 2. Descriptive statistics.

\begin{tabular}{cccccccc}
\hline & \multicolumn{2}{c}{ Mean } & $\begin{array}{c}\text { Student } \\
\text { Deviation }\end{array}$ & Skewness & \multicolumn{2}{c}{ Kurtosis } \\
\cline { 2 - 8 } & Statistic & $\begin{array}{c}\text { Student } \\
\text { Error }\end{array}$ & Statistic & Statistic & $\begin{array}{c}\text { Student } \\
\text { Error }\end{array}$ & $\begin{array}{c}\text { Statistic } \\
\text { Student } \\
\text { Error }\end{array}$ \\
\hline $\begin{array}{c}\text { Performance of } \\
\text { Students }\end{array}$ & 3.81 & 0.038 & 1.075 & -0.899 & 0.087 & 0.287 & 0.174 \\
\hline SMS & 3.77 & 0.038 & 1.072 & -0.827 & 0.087 & 0.190 & 0.174 \\
\hline MMS & 3.95 & 0.039 & 1.100 & -0.965 & 0.087 & 0.340 & 0.174 \\
\hline Mobile Apps & 3.97 & 0.040 & 1.113 & -0.977 & 0.087 & 0.288 & 0.174 \\
\hline $\begin{array}{c}\text { Warp-Speed } \\
\text { Processing }\end{array}$ & 3.85 & 0.037 & 1.047 & -0.939 & 0.087 & 0.570 & 0.174 \\
\hline Entertainment & 3.50 & 0.036 & 1.020 & -0.550 & 0.087 & -0.305 & 0.174 \\
\hline Attitude & 3.84 & 0.037 & 1.038 & -0.941 & 0.087 & 0.620 & 0.174 \\
\hline EWOM & 3.93 & 0.039 & 1.095 & -0.953 & 0.087 & 0.343 & 0.174 \\
\hline Technology & 3.91 & 0.039 & 1.083 & -0.947 & 0.087 & 0.397 & 0.174 \\
\hline Addiction & 3.78 & 0.036 & 0.996 & -0.978 & 0.087 & 0.896 & 0.174 \\
\hline
\end{tabular}

Table 3. Analysis of reliabilities and validities.

\begin{tabular}{|c|c|c|c|c|c|}
\hline Variables/Factors & Constructs & FL & CA & CR & AVE \\
\hline \multirow{3}{*}{ Performance of Students } & POS1 & 0.732 & \multirow{3}{*}{0.849} & \multirow{3}{*}{0.718} & \multirow{3}{*}{0.729} \\
\hline & POS2 & 0.880 & & & \\
\hline & POS3 & 0.936 & & & \\
\hline \multirow{3}{*}{ Multimedia Message Service } & MMS1 & 0.829 & \multirow{3}{*}{0.827} & \multirow{3}{*}{0.713} & \multirow{3}{*}{0.687} \\
\hline & MMS2 & 0.905 & & & \\
\hline & MMS3 & 0.746 & & & \\
\hline \multirow{3}{*}{ Simple Message Service } & SMS1 & 0.931 & \multirow{3}{*}{0.821} & \multirow{3}{*}{0.711} & \multirow{3}{*}{0.682} \\
\hline & SMS2 & 0.831 & & & \\
\hline & SMS3 & 0.701 & & & \\
\hline \multirow{3}{*}{ Mobile Applications } & MAP1 & 0.900 & \multirow{3}{*}{0.812} & \multirow{3}{*}{0.709} & \multirow{3}{*}{0.665} \\
\hline & MAP2 & 0.820 & & & \\
\hline & MAP3 & 0.716 & & & \\
\hline \multirow{3}{*}{ Warp-Speed Processing } & WSP1 & 0.826 & \multirow{3}{*}{0.854} & \multirow{3}{*}{0.719} & \multirow{3}{*}{0.731} \\
\hline & WSP2 & 0.905 & & & \\
\hline & WSP3 & 0.832 & & & \\
\hline \multirow{3}{*}{ Entertainment } & ENT1 & 0.812 & \multirow{3}{*}{0.832} & \multirow{3}{*}{0.714} & \multirow{3}{*}{0.699} \\
\hline & ENT2 & 0.943 & & & \\
\hline & ENT3 & 0.742 & & & \\
\hline \multirow{3}{*}{ Electronic Word of Mouth } & EWOM1 & 0.782 & \multirow{3}{*}{0.848} & \multirow{3}{*}{0.717} & \multirow{3}{*}{0.723} \\
\hline & EWOM2 & 0.932 & & & \\
\hline & EWOM3 & 0.831 & & & \\
\hline \multirow{3}{*}{ Attitude } & ATT1 & 0.832 & \multirow{3}{*}{0.806} & \multirow{3}{*}{0.707} & \multirow{3}{*}{0.651} \\
\hline & ATT2 & 0.845 & & & \\
\hline & ATT3 & 0.740 & & & \\
\hline
\end{tabular}


Table 3. Cont.

\begin{tabular}{cccccc}
\hline Variables/Factors & Constructs & FL & CA & CR & AVE \\
\hline \multirow{3}{*}{ Technology } & TEC1 & 0.827 & & & \\
& TEC2 & 0.703 & 0.820 & 0.711 & 0.681 \\
& TEC3 & 0.931 & & & \\
\hline \multirow{3}{*}{ Addiction } & ADD1 & 0.721 & & & \\
& ADD2 & 0.903 & 0.818 & 0.710 & 0.675 \\
& ADD3 & 0.831 & & & \\
\hline
\end{tabular}

\subsection{Exploratory Factor Analysis-EFA}

Researchers employed the EFA technique to ascertain the fitness and reduction of sample data through the validation process $[115,116]$. The rotated component matrix was extracted through principal component analysis, which also authenticated the validation of items and factors of the sample data. The undertaken research consists of ten variables and 30 items in which performance of students (POS), multimedia message service (SMS), short message service (SMS), mobile applications (MAP), warp-speed processing (WSP), entertainment (ENT), electronic word of mouth (eWOM), attitude (ATT), technology (TEC), and addiction (ADD) have three constructs each. Table 4 exhibited that the factor loading of each item is more than 0.50 , which confirmed and validated all items and factors, which researchers loaded for the undertaken study [106,110,117].

Table 4. Principal component analysis. Rotated component matrix ${ }^{\mathrm{a}}$.

\begin{tabular}{|c|c|c|c|c|c|c|c|c|c|c|c|}
\hline \multirow{2}{*}{ Factors } & \multirow{2}{*}{ Items } & \multicolumn{10}{|c|}{ Components } \\
\hline & & 1 & 2 & 3 & 4 & 5 & 6 & 7 & 8 & 9 & 10 \\
\hline \multirow{3}{*}{$\begin{array}{l}\text { Performance of } \\
\text { Students }\end{array}$} & POS1 & 0.732 & & & & & & & & & \\
\hline & POS2 & 0.880 & & & & & & & & & \\
\hline & POS3 & 0.936 & & & & & & & & & \\
\hline \multirow{3}{*}{$\begin{array}{l}\text { Simple } \\
\text { Message } \\
\text { Service }\end{array}$} & SMS1 & & 0.931 & & & & & & & & \\
\hline & SMS2 & & 0.831 & & & & & & & & \\
\hline & SMS3 & & 0.701 & & & & & & & & \\
\hline \multirow{3}{*}{$\begin{array}{l}\text { Multimedia } \\
\text { Message } \\
\text { Service }\end{array}$} & MMS1 & & & 0.829 & & & & & & & \\
\hline & MMS2 & & & 0.905 & & & & & & & \\
\hline & MMS3 & & & 0.746 & & & & & & & \\
\hline \multirow{3}{*}{ Mobile Apps } & MAP1 & & & & 0.900 & & & & & & \\
\hline & MAP2 & & & & 0.820 & & & & & & \\
\hline & MAP3 & & & & 0.716 & & & & & & \\
\hline \multirow{3}{*}{ Technology } & TEC1 & & & & & 0.827 & & & & & \\
\hline & TEC2 & & & & & 0.703 & & & & & \\
\hline & TEC3 & & & & & 0.931 & & & & & \\
\hline \multirow{3}{*}{ Addiction } & ADD1 & & & & & & 0.721 & & & & \\
\hline & ADD2 & & & & & & 0.903 & & & & \\
\hline & ADD3 & & & & & & 0.831 & & & & \\
\hline \multirow{3}{*}{$\begin{array}{l}\text { Warp-Speed } \\
\text { Processing }\end{array}$} & WSP1 & & & & & & & 0.826 & & & \\
\hline & WSP2 & & & & & & & 0.905 & & & \\
\hline & WSP3 & & & & & & & 0.832 & & & \\
\hline
\end{tabular}


Table 4. Cont.

\begin{tabular}{|c|c|c|c|c|c|c|c|c|c|c|c|}
\hline \multirow{2}{*}{ Factors } & \multirow{2}{*}{ Items } & \multicolumn{10}{|c|}{ Components } \\
\hline & & 1 & 2 & 3 & 4 & 5 & 6 & 7 & 8 & 9 & 10 \\
\hline \multirow{3}{*}{ Entertainment } & ENT1 & & & & & & & & 0.812 & & \\
\hline & ENT2 & & & & & & & & 0.943 & & \\
\hline & ENT3 & & & & & & & & 0.742 & & \\
\hline \multirow{3}{*}{ Attitude } & ATT1 & & & & & & & & & 0.832 & \\
\hline & ATT2 & & & & & & & & & 0.845 & \\
\hline & ATT3 & & & & & & & & & 0.740 & \\
\hline \multirow{3}{*}{$\begin{array}{c}\text { Electronic } \\
\text { word of mouth }\end{array}$} & EWOM1 & & & & & & & & & & 0.782 \\
\hline & EWOM2 & & & & & & & & & & 0.932 \\
\hline & EWOM3 & & & & & & & & & & 0.831 \\
\hline
\end{tabular}

Extraction method: Principal component analysis. Rotation method: Varimax with Kaiser normalization. ${ }^{\text {a }}$ Rotation converged in 5 iterations.

\subsection{Kaiser Meyer Olkin (KMO) and Bartlett's Techniques}

Researchers examined the appropriateness and fitness of ample data through Kaiser Meyer Olkin (KMO) analysis and Bartlett's Sphericity test. Table 5 exhibited that the KMO value is 0.811 , which is equitably excellent since the values ranging from $0.70-0.79$ are considered to be good, and ranging from 0.80-0.99 are considered excellent [12,117]. Table 4 also demonstrated the results of Bartlett's Sphericity test, which showed probability is less than 0.50 , i.e., 0.000 , which indicated the correlation between items is cogent and adequate at a $\%$ significance level.

Table 5. Kaiser Meyer Olkin (KMO) and Bartlett's techniques.

\begin{tabular}{|c|c|c|}
\hline Kaiser-Meyer-Olkin Measu & of Sampling Adequacy & 0.811 \\
\hline \multirow{3}{*}{ Bartlett's Test of Sphericity } & Approx. Chi-Square & $21,599.816$ \\
\hline & Df & 435 \\
\hline & Sig. & 0.000 \\
\hline
\end{tabular}

\subsection{Total Variance Explained}

The cumulative percentage of variance for thirteen factors demonstrated the dispersion of the variance of these potential factors; the total value of Eigen is greater than 1, which further established the amount of variance amongst prospective factors. The cumulative variance is $87.47 \%$, which is considered to be very good since the minimum threshold value is $50 \%$ as shown in Table 6 . Hence, based on total eigenvalue and cumulative variance, it is concluded that the data sample is considered reliable, and an SEM-based multivariate approach can be employed [12,109].

\subsection{Anti-Image Correlation Matrix (AICM)}

The outcomes of Table 7 exhibited that the diagonal of the anti-image correlation matrix (AICM) is greater than the values of 0.50 , thus it is further concluded that our considered variables are suitable for the undertaken study and we can proceed for further analysis. 
Table 6. Total variance explained.

\begin{tabular}{|c|c|c|c|c|c|c|c|c|c|}
\hline \multirow{2}{*}{ 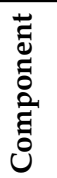 } & \multicolumn{3}{|c|}{ Initial Eigenvalues } & \multicolumn{3}{|c|}{$\begin{array}{c}\text { Extraction Sums of Squared } \\
\text { Loadings }\end{array}$} & \multicolumn{3}{|c|}{$\begin{array}{c}\text { Rotation Sums of Squared } \\
\text { Loadings }\end{array}$} \\
\hline & Total & $\begin{array}{c}\% \text { of } \\
\text { Variance }\end{array}$ & $\begin{array}{c}\text { Cumulative } \\
\%\end{array}$ & Total & $\begin{array}{c}\% \text { of } \\
\text { Variance }\end{array}$ & $\begin{array}{c}\text { Cumulative } \\
\%\end{array}$ & Total & $\begin{array}{c}\% \text { of } \\
\text { Variance }\end{array}$ & $\begin{array}{c}\text { Cumulative } \\
\%\end{array}$ \\
\hline 1 & 7.581 & 25.268 & 25.268 & 7.581 & 25.268 & 25.268 & 7.558 & 25.194 & 25.194 \\
\hline 2 & 2.935 & 9.783 & 35.051 & 2.935 & 9.783 & 35.051 & 2.592 & 8.641 & 33.835 \\
\hline 3 & 2.641 & 8.802 & 43.853 & 2.641 & 8.802 & 43.853 & 2.590 & 8.632 & 42.467 \\
\hline 4 & 2.604 & 8.682 & 52.535 & 2.604 & 8.682 & 52.535 & 2.563 & 8.545 & 51.011 \\
\hline 5 & 2.504 & 8.345 & 60.880 & 2.504 & 8.345 & 60.880 & 2.557 & 8.524 & 59.535 \\
\hline 6 & 2.280 & 7.600 & 68.480 & 2.280 & 7.600 & 68.480 & 2.536 & 8.452 & 67.988 \\
\hline 7 & 1.821 & 6.072 & 74.552 & 1.821 & 6.072 & 74.552 & 1.798 & 5.992 & 73.979 \\
\hline 8 & 1.743 & 5.809 & 80.361 & 1.743 & 5.809 & 80.361 & 1.794 & 5.982 & 79.961 \\
\hline 9 & 1.630 & 5.433 & 85.794 & 1.630 & 5.433 & 85.794 & 1.750 & 5.833 & 85.794 \\
\hline 10 & 1.528 & 5.283 & 87.479 & 1.528 & 5.283 & 87.479 & 1.740 & 5.496 & 87.479 \\
\hline
\end{tabular}

Extraction method: principal component analysis.

Table 7. Outcomes of AICM (anti-image correlation matrices).

\begin{tabular}{|c|c|c|c|c|c|c|c|c|c|c|c|}
\hline & Factors & POS & SMS & MMS & MAP & WSP & ENT & ATT & EWOM & TEC & ADD \\
\hline \multirow{10}{*}{ 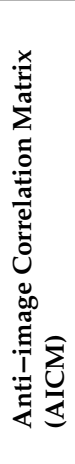 } & POS & $0.799^{a}$ & -0.484 & -0.627 & 0.154 & 0.268 & -0.424 & -0.313 & -0.510 & 0.276 & 0.296 \\
\hline & SMS & -0.484 & $0.785^{a}$ & 0.653 & -0.219 & -0.543 & 0.373 & 0.143 & 0.057 & -0.113 & -0.518 \\
\hline & MMS & -0.627 & 0.653 & $0.740^{a}$ & -0.239 & -0.532 & 0.481 & 0.290 & -0.014 & -0.019 & -0.718 \\
\hline & Mobile Apps & 0.154 & -0.219 & -0.239 & $0.879^{a}$ & 0.365 & 0.037 & -0.665 & -0.094 & -0.297 & -0.120 \\
\hline & WSP & 0.268 & -0.543 & -0.532 & 0.365 & $0.810^{a}$ & -0.135 & -0.496 & -0.142 & -0.333 & 0.402 \\
\hline & Entertainment & -0.424 & 0.373 & 0.481 & 0.037 & -0.135 & $0.701^{a}$ & -0.028 & 0.135 & -0.310 & -0.283 \\
\hline & Attitude & -0.313 & 0.143 & 0.290 & -0.665 & -0.496 & -0.028 & $0.861^{a}$ & 0.100 & 0.132 & -0.132 \\
\hline & EWOM & -0.510 & 0.057 & -0.014 & -0.094 & -0.142 & 0.135 & 0.100 & $0.923^{a}$ & -0.371 & 0.119 \\
\hline & Technology & 0.276 & -0.113 & -0.019 & -0.297 & -0.333 & -0.310 & 0.132 & -0.371 & $0.910^{a}$ & -0.143 \\
\hline & Addiction & 0.296 & -0.518 & -0.718 & -0.120 & 0.402 & -0.283 & -0.132 & 0.119 & -0.143 & $0.824^{a}$ \\
\hline
\end{tabular}

\subsection{Confirmatory Factor Analysis-CFA}

According to Hair et al. [111], the CFA is an appropriate and direct approach to check the measurement model, moreover, the CFA analysis examines whether data fit a hypothesized measurement model. In the considered measured model, researchers confirm the factors of the smartphone such as multimedia message service, short message service, mobile applications, warp-speed processing, entertainment, whereas, technology and addiction as moderating variables, and electronic word of mouth and attitude as mediating factors, and students' academic performance in universities as outcome variable. Researchers have incorporated thirty items of all ten factors into the confirmatory factor analysis, and fixing the sample data between unobserved and observed [12,113]. The outcomes of Table 5 demonstrated the considered hypothesized measured model is adequate because the fit indices are within the threshold limits such as RMSEA: 0.032, GFI: 0.96, CFI: 0.97, NFI: 0.931, IFI: 0.961, PNFI: 0.679, and PCFI: 0.737.

\subsection{Structural Equation Modeling-SEM}

For the estimation of the purchase decision, researchers have employed structural equation modeling. Researchers have incorporated multimedia message service, short message service, mobile applications, warp-speed processing, and entertainment as independent variables, whereas, 
technology and addiction as moderating variables, and electronic word of mouth and attitude as mediating factors, and student academic performance in universities as an outcome variable in our considered structural model. The results of Table 8 exhibited that the fit-indices demonstrate that the entire structured model is acceptable because the fit indices are within the threshold values such as RMSEA: 0.021, GFI: 0.97, CFI: 0.98, NFI: 0.912, IFI: 0.955, PNFI: 0.725, and PCFI: 0.728.

Table 8. Model fit indices.

\begin{tabular}{cccccccc}
\hline Fit Indices & RMSEA & GFI & CFI & NFI & IFI & PNFI & PCFI \\
\hline Criteria & $\leq 0.05$ & $>0.95$ & $\geq 0.95$ & $>0.90$ & $>0.95$ & $>0.50$ & $>0.50$ \\
\hline Structural model & 0.021 & 0.97 & 0.98 & 0.912 & 0.955 & 0.725 & 0.728 \\
\hline Measurement Model & 0.032 & 0.96 & 0.97 & 0.931 & 0.961 & 0.679 & 0.737
\end{tabular}

PCFI: Parsimony-adjusted comparative fit index, CFI: comparative fit index; GFI: goodness of fit index; NFI: normed fixed index; RMSEA: root mean square error of approximation; PNFI: parsimony-adjusted normed fixed index; IFI: incremental fit index.

\subsection{Hypothesized Direct Relationship}

Researchers used standardized regression weights (SRW) for interpreting a direct relationship between functions of smartphones such as multimedia message service, short message service, mobile applications, warp-speed processing, entertainment, and dependent variable (performance of students). Outcomes of Table 9 exhibited that four hypotheses H1-H5 are supported ( $\mathrm{T}>2$ and $p<0.05$ ); however, the hypothesis regarding short message service (H2) is rejected. Thus, it is finally, concluded that multimedia message service, mobile applications, warp-speed processing, and entertainment have a significant impact on student academic performance in universities as the outcome variable, and short message service does not have any impact on student performance. Outcomes of individual variables signified that warp-speed processing and multimedia message service have the highest impacts of 0.8079 , and 0.3547 , respectively. However, mobile applications followed with the impact of 0.0860 , and entertainment has a negative but significant impact i.e., -0.1414 on the academic performance of students.

Table 9. Hypothesized direct relationship.

\begin{tabular}{cccccccc}
\hline & Regression \\
Paths & $\begin{array}{c}\text { Standard. } \\
\text { Regression } \\
\text { Weights }\end{array}$ & SE & T & $p$ & Decision \\
\hline $\mathrm{H} 1$ & $\begin{array}{c}\text { Multimedia } \\
\text { Message Service }\end{array}$ & MMS $\rightarrow$ POS & 0.3547 & 0.025 & 14.27 & 0.000 & Supported \\
\hline $\mathrm{H} 2$ & $\begin{array}{c}\text { Short Message } \\
\text { Service }\end{array}$ & SMS $\rightarrow$ POS & 0.0205 & 0.036 & 0.56 & 0.571 & $\begin{array}{c}\text { Not } \\
\text { Supported }\end{array}$ \\
\hline $\mathrm{H} 3$ & Mobile Applications & MAP $\rightarrow$ POS & 0.0860 & 0.026 & 3.27 & 0.001 & Supported \\
\hline $\mathrm{H} 4$ & $\begin{array}{c}\text { Warp-Speed } \\
\text { Processing }\end{array}$ & WSP $\rightarrow$ POS & 0.8079 & 0.063 & 12.65 & 0.000 & Supported \\
\hline $\mathrm{H} 5$ & Entertainment & ENT $\rightarrow$ POS & -0.1414 & 0.073 & -2.107 & 0.041 & Supported \\
\hline
\end{tabular}

\subsection{Indirect Hypothesized Relationship (Mediation)}

The results of Table 10 demonstrated the significant influence of mediating variables such as electronic word of mouth (eWOM) and attitude in an association of exogenous variables such as multimedia message service, short message service, mobile applications, warp-speed processing, entertainment, and endogenous variable i.e., academic performance of students. The results of mediation were extracted through normal theory and bootstrapping methods. Researchers formulated 
two sets of five hypotheses such as (H6A-H6E), and (H7A-H7E), the results of the bootstrapping method exhibited that the decision of all the hypotheses is supported (zero does not occur between BootLLCI and BootULCI) [109,118]. Hence, it is established that eWOM and attitude have a significant mediating effect amongst exogenous variables and endogenous variable i.e., academic performance of students. The outcomes of the normal theory method demonstrated similar results and concluded the same inference because $\mathrm{z}> \pm 1.96$, and corresponding probabilities are less than 0.05 in all the cases. Hence, it is finally concluded that eWOM and attitude are significant mediators, which have a significant impact amongst all the exogenous variables, and endogenous variables $[12,110]$.

Table 10. Mediation analysis.

\begin{tabular}{|c|c|c|c|c|c|c|c|c|c|}
\hline & \multirow[b]{2}{*}{ Mediation } & \multicolumn{4}{|c|}{ Bootstrapping Method } & \multicolumn{4}{|c|}{ Normal Theory Method } \\
\hline & & $\begin{array}{c}\text { Indirect } \\
\text { Effect }\end{array}$ & $\begin{array}{c}\text { Boot } \\
\text { SE }\end{array}$ & $\begin{array}{l}\text { Boot } \\
\text { LLCI }\end{array}$ & $\begin{array}{l}\text { Boot } \\
\text { ULCI }\end{array}$ & $\begin{array}{c}\text { Indirect } \\
\text { Effect }\end{array}$ & SE & $Z^{*}$ & $\underset{* *}{\text { Prob. }}$ \\
\hline H6A: & $\mathrm{MMS} \rightarrow \mathrm{eWOM} \rightarrow \mathrm{POS}$ & 0.372 & 0.027 & 0.318 & 0.425 & 0.372 & 0.023 & 15.82 & 0.000 \\
\hline H6B: & $\mathrm{SMS} \rightarrow \mathrm{eWOM} \rightarrow \mathrm{POS}$ & 0.505 & 0.025 & 0.455 & 0.556 & 0.505 & 0.024 & 20.69 & 0.000 \\
\hline H6C: & $\mathrm{MAP} \rightarrow \mathrm{eWOM} \rightarrow \mathrm{POS}$ & 0.527 & 0.026 & 0.477 & 0.577 & 0.527 & 0.024 & 22.06 & 0.000 \\
\hline H6D: & $\mathrm{WSP} \rightarrow \mathrm{eWOM} \rightarrow \mathrm{POS}$ & 0.581 & 0.025 & 0.530 & 0.630 & 0.581 & 0.027 & 20.99 & 0.000 \\
\hline H6E: & $\mathrm{ENT} \rightarrow \mathrm{eWOM} \rightarrow$ POS & 0.049 & 0.030 & 0.010 & 0.019 & 0.049 & 0.025 & 1.99 & 0.046 \\
\hline H7A: & $\mathrm{MMS} \rightarrow \mathrm{ATT} \rightarrow \mathrm{POS}$ & 0.150 & 0.017 & 0.116 & 0.186 & 0.150 & 0.018 & 8.12 & 0.000 \\
\hline H7B: & $\mathrm{SMS} \rightarrow \mathrm{ATT} \rightarrow \mathrm{POS}$ & 0.213 & 0.034 & 0.146 & 0.282 & 0.213 & 0.024 & 8.83 & 0.000 \\
\hline H7C: & $\mathrm{MAP} \rightarrow \mathrm{ATT} \rightarrow \mathrm{POS}$ & 0.255 & 0.028 & 0.201 & 0.315 & 0.255 & 0.033 & 7.75 & 0.000 \\
\hline H7D: & $\mathrm{WSP} \rightarrow \mathrm{ATT} \rightarrow \mathrm{POS}$ & 0.265 & 0.035 & 0.196 & 0.335 & 0.265 & 0.026 & 9.93 & 0.000 \\
\hline H7E: & $\mathrm{ENT} \rightarrow \mathrm{ATT} \rightarrow \mathrm{POS}$ & 0.042 & 0.013 & 0.016 & 0.069 & 0.042 & 0.012 & 3.63 & 0.000 \\
\hline
\end{tabular}

\subsection{Hypothesized Relationship of Moderation}

Outcomes of Table 11 exhibited the moderating effects of technology and addiction in the relationship of exogenous variables such as multimedia message service, short message service, mobile applications, warp-speed processing, entertainment, and endogenous variable i.e., academic performance of students. Researchers formulated two sets of five hypotheses such as (H8A-H8E) and (H9A-H9E), and the outcomes of Table 11 demonstrated that all the hypotheses are accepted $(p<0.05)$. Thus, it is conclusively established that technology and addiction are the significant moderators, which have a significant impact amongst all the exogenous variables such as multimedia message service, short message service, mobile applications, warp-speed processing, entertainment, and endogenous variable. Table 11 exhibited the detailed outcomes of hypotheses (H8A-H8E) and (H9A-H9E).

Table 11. Moderating effect.

\begin{tabular}{ccccccccc}
\hline Hypotheses & Moderator & Moderation & Effect & SE & T & $p^{*}$ & LLCI & ULCI \\
\hline \multicolumn{7}{c}{ Moderating Effects of TEC and ADD b/w MMS and POS } & & \\
\hline H8A: & TEC & MMS $\times$ TEC & -0.081 & 0.013 & -6.01 & 0.000 & -0.107 & -0.054 \\
\hline H9A: & ADD & MMS $\times$ ADD & -0.128 & 0.012 & -10.36 & 0.000 & -0.152 & -0.104 \\
\hline \multicolumn{7}{c}{ Moderating Effects of TEC and ADD b/w SMS and POS } & & \\
\hline H8B: & TEC & SMS $\times$ TEC & -0.232 & 0.014 & -15.80 & 0.000 & -0.261 & -0.203 \\
\hline H9B: & ADD & SMS $\times$ ADD & -0.183 & 0.017 & -10.66 & 0.000 & -0.216 & -0.149 \\
\hline
\end{tabular}


Table 11. Cont.

\begin{tabular}{ccccccccc}
\hline Hypotheses & Moderator & Moderation & Effect & SE & T & $p^{*}$ & LLCI & ULCI \\
\hline \multicolumn{7}{c}{ Moderating Effects of TEC and ADD b/w MAP and POS } & & \\
\hline H8C: & TEC & MAP $\times$ TEC & -0.178 & 0.014 & -12.14 & 0.000 & -0.207 & -0.149 \\
\hline H9C: & ADD & MAP $\times$ ADD & -0.171 & 0.014 & -11.46 & 0.000 & -0.200 & -0.142 \\
\hline \multicolumn{7}{c}{ Moderating Effects of TEC and ADD b/w WSP and POS } \\
\hline H8D: & TEC & WSP $\times$ TEC & -0.169 & 0.014 & -11.37 & 0.000 & -0.198 & -0.140 \\
\hline H9D: & ADD & WSP $\times$ ADD & -0.084 & 0.018 & -4.68 & 0.000 & -0.120 & -0.049 \\
\hline H8E: & TEC & ENT $\times$ TEC & -0.051 & 0.019 & -2.64 & 0.008 & -0.088 & -0.013 \\
\hline H9E: & ADD & ENT $\times$ ADD & 0.060 & 0.019 & 3.05 & 0.002 & 0.021 & 0.098 \\
\hline
\end{tabular}

\subsection{D Graphical Representation of the Conditional Impact}

Figures 2-11 exhibited the conditional visualizing impact of moderating variables (technology and addiction) between smartphone functions such as multimedia message service, short message service, mobile applications, warp-speed processing, entertainment, and endogenous variable i.e., student academic performance in universities. Figures 2-11 exhibited the graphical depiction of moderation of technology and addiction in a relationship between exogenous variables and student academic performance in universities as outcome variable. As the outcome variable changes with every reading of moderating variables, thus, this variation demonstrated a significant influence of moderators. The graphical representation is an important condition for demonstrating the influence of the moderator because the ultimate graphical evidence is the final proof of moderation $[12,109,118]$. From Figures 2-11, the red color depicts the independent variables, however, orange color shows the impact of moderating variables, whereas, the green color demonstrates the academic performance of university students.

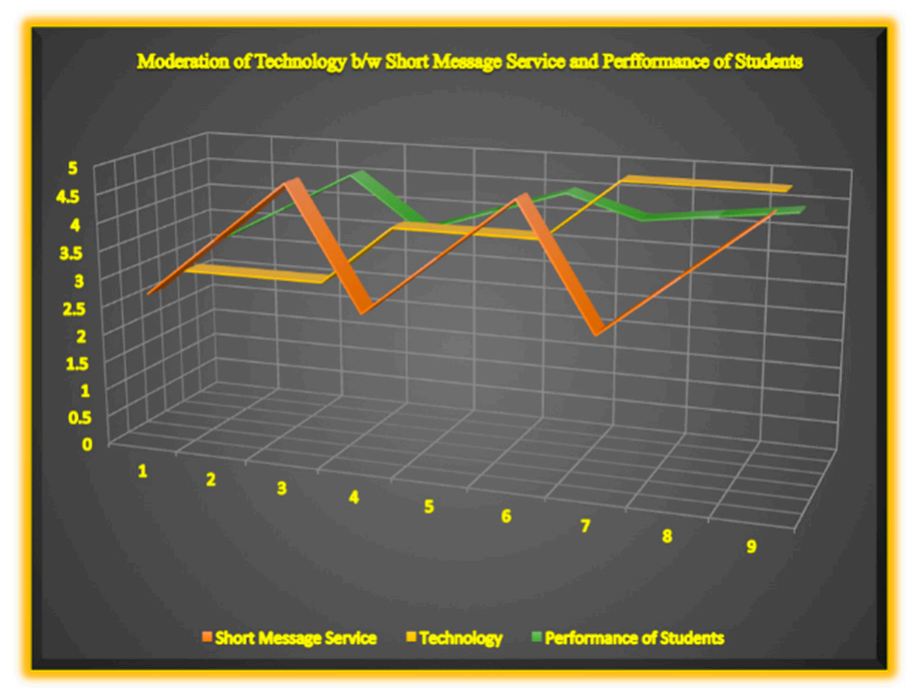

Figure 2. Visualization of 3D graphs for the conditional moderating effect of addiction and technology. 


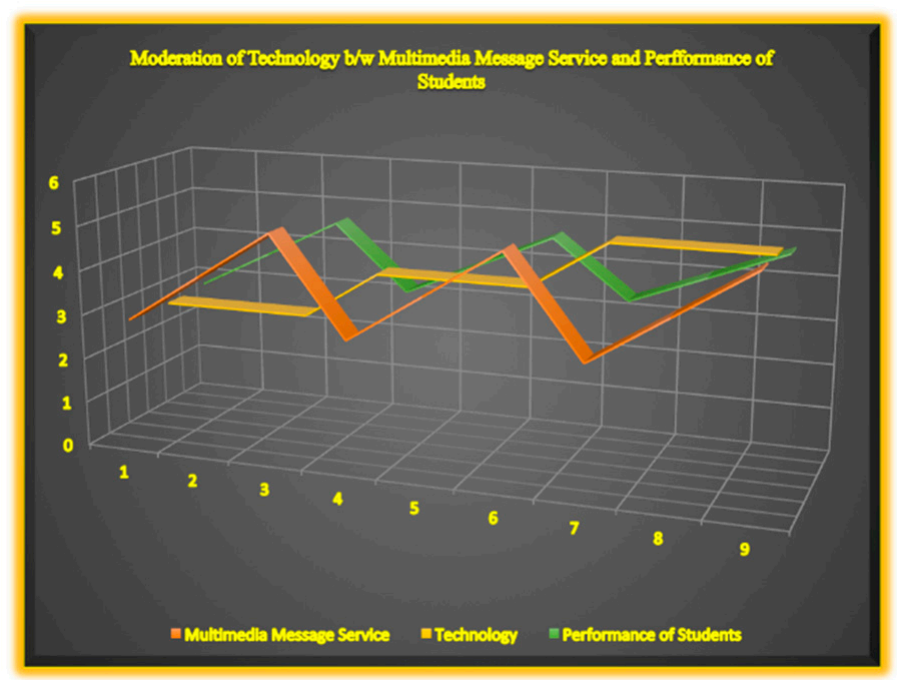

Figure 3. Visualization of 3D graphs for the conditional moderating effect of addiction and technology.

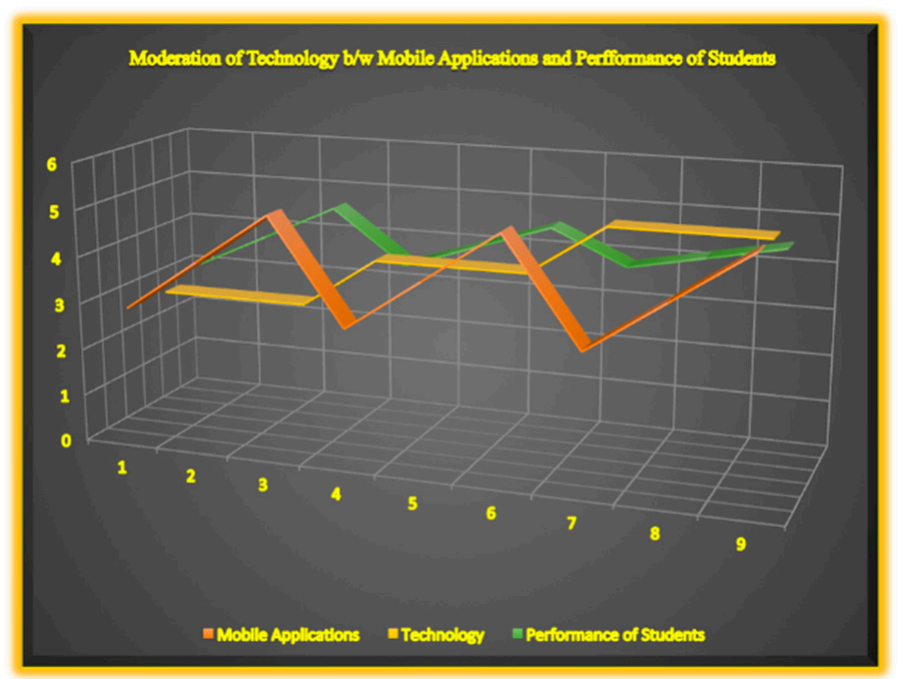

Figure 4. Visualization of 3D graphs for the conditional moderating effect of addiction and technology.

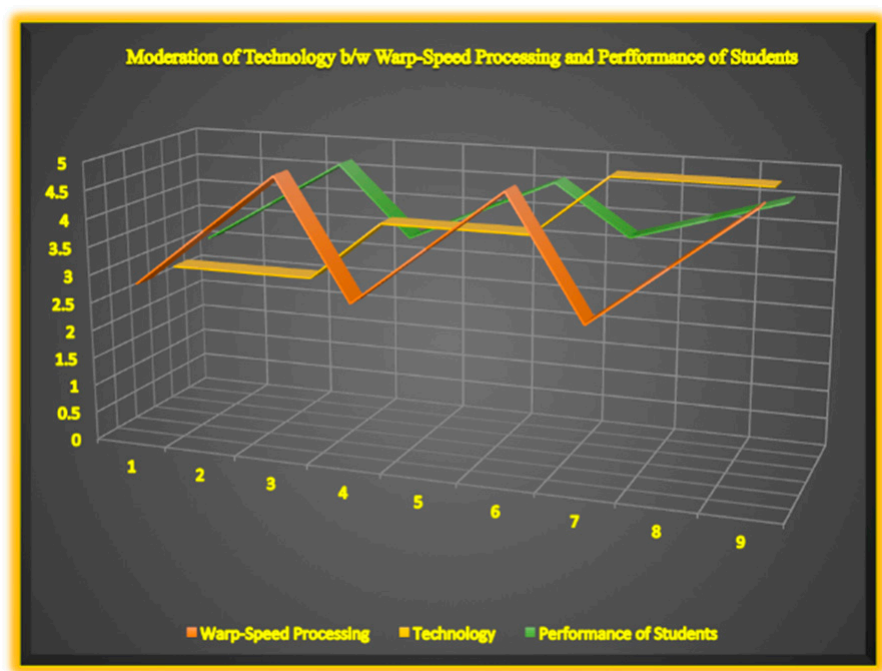

Figure 5. Visualization of 3D graphs for the conditional moderating effect of addiction and technology. 


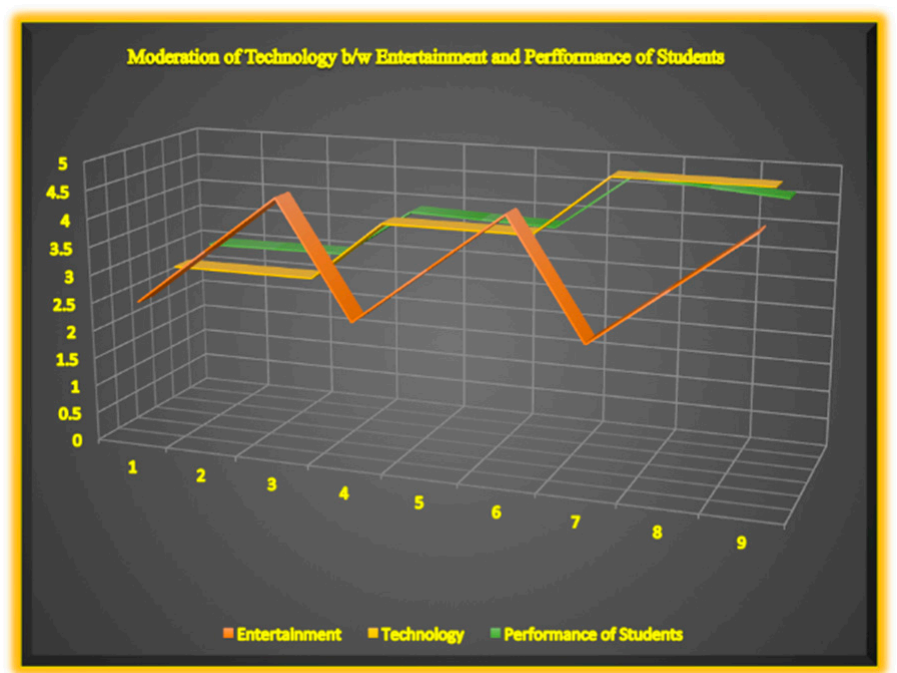

Figure 6. Visualization of 3D graphs for the conditional moderating effect of addiction and technology.

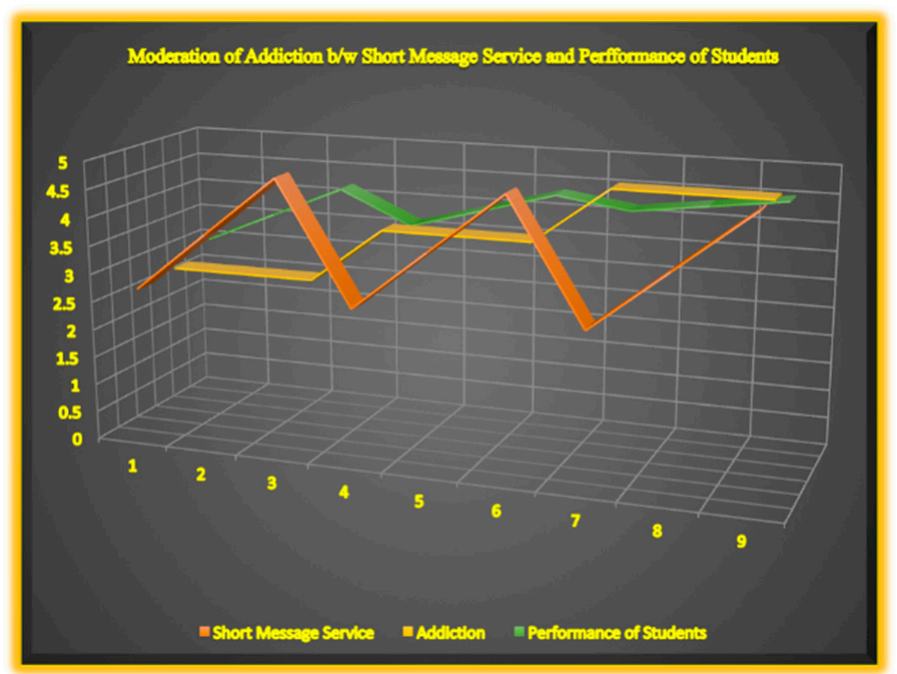

Figure 7. Visualization of 3D graphs for the conditional moderating effect of addiction and technology.

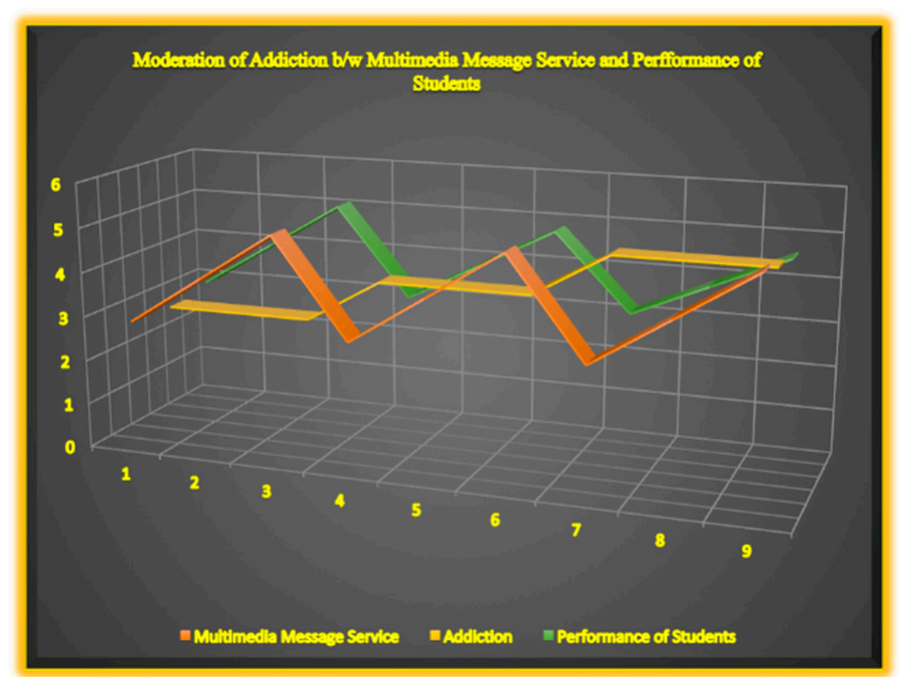

Figure 8. Visualization of 3D graphs for the conditional moderating effect of addiction and technology. 


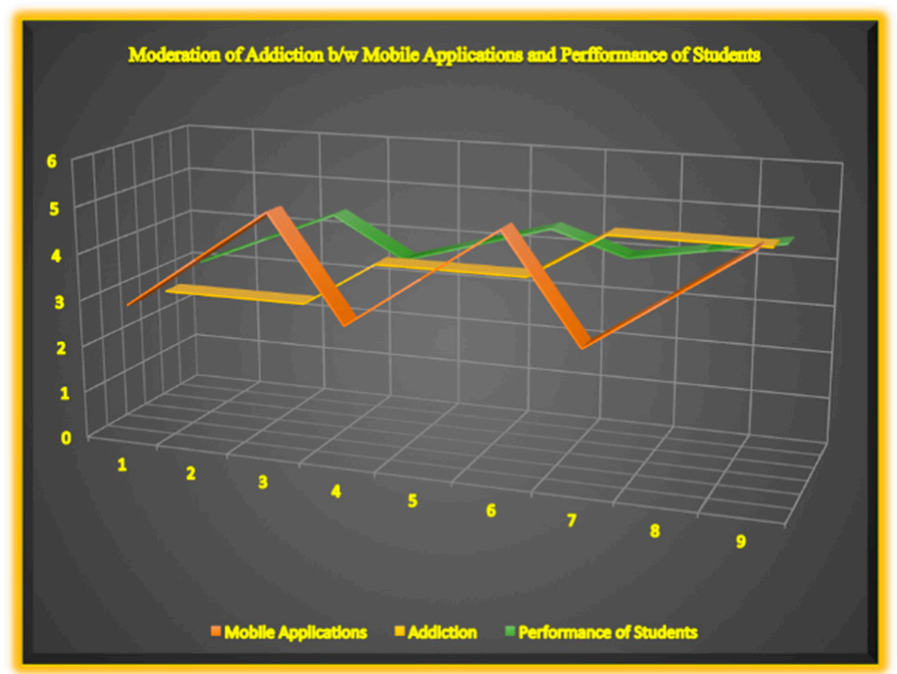

Figure 9. Visualization of 3D graphs for the conditional moderating effect of addiction and technology.

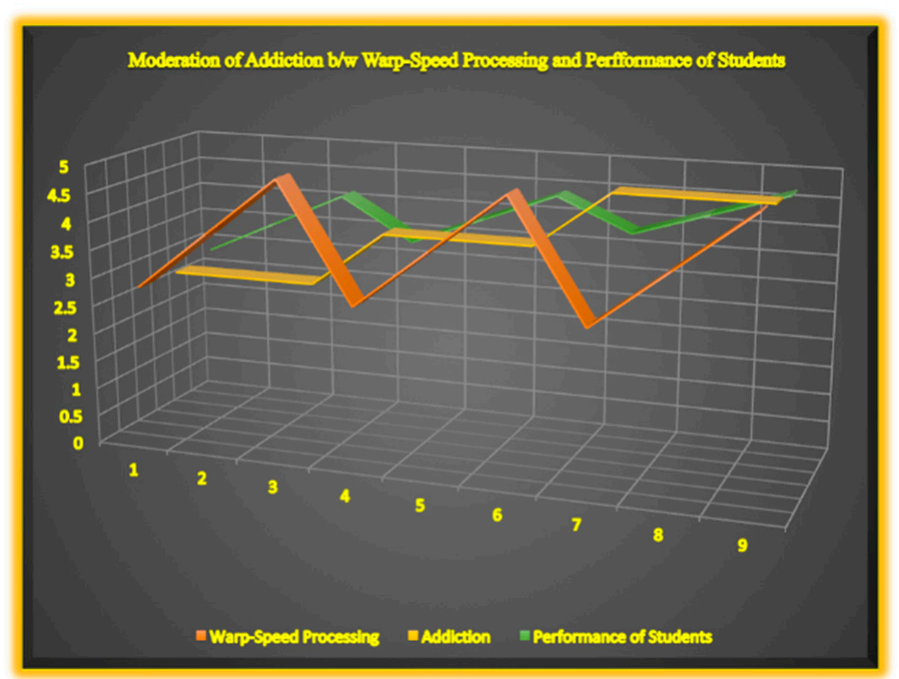

Figure 10. Visualization of 3D graphs for the conditional moderating effect of addiction and technology.

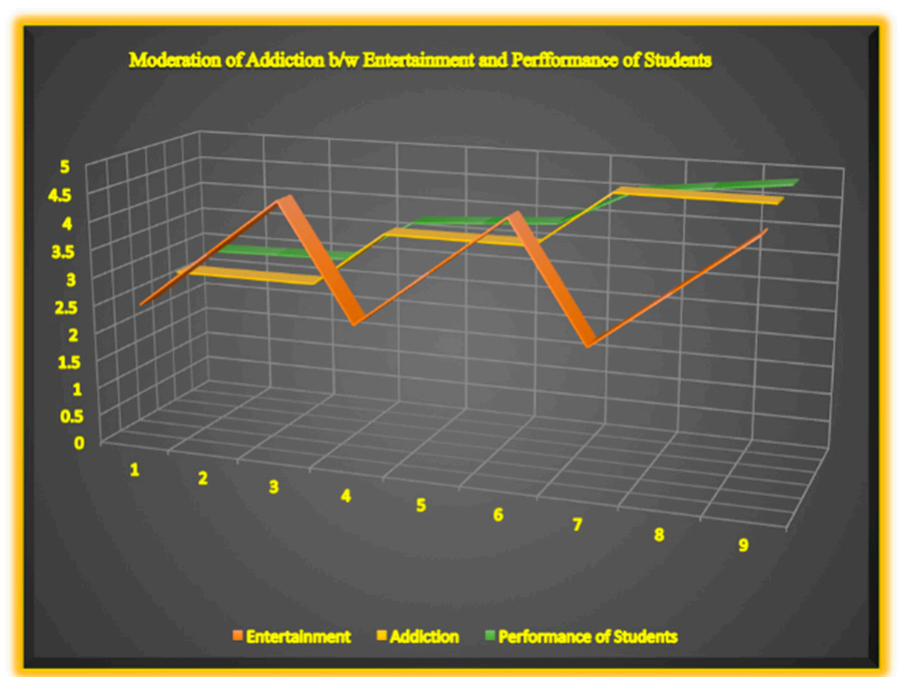

Figure 11. Visualization of 3D graphs for the conditional moderating effect of addiction and technology. 
The summary of outcomes of hypothesized direct and indirect relationship has been presented in Table 12:

Table 12. Summary of the hypotheses.

\begin{tabular}{|c|c|c|c|c|c|}
\hline $\begin{array}{c}\text { Serial. } \\
\text { Number. }\end{array}$ & Hypotheses & Relationship & $\begin{array}{c}\text { Variables } \\
\text { Relationship }\end{array}$ & Outcome & Decision \\
\hline 1 & $\mathrm{H} 1$ & Direct & $\mathrm{MMS} \rightarrow \mathrm{POS}$ & Significant & Accepted \\
\hline 2 & $\mathrm{H} 2$ & Direct & $\mathrm{SMS} \rightarrow \mathrm{POS}$ & Insignificant & Rejected \\
\hline 3 & $\mathrm{H} 3$ & Direct & $\mathrm{MAP} \rightarrow \mathrm{POS}$ & Significant & Accepted \\
\hline 4 & $\mathrm{H} 4$ & Direct & $\mathrm{WSP} \rightarrow \mathrm{POS}$ & Significant & Accepted \\
\hline 5 & H5 & Direct & $\mathrm{ENT} \rightarrow \mathrm{POS}$ & Significant & Accepted \\
\hline 6 & H6A & Mediation & $\mathrm{MMS} \rightarrow \mathrm{eWOM} \rightarrow \mathrm{POS}$ & Significant & Accepted \\
\hline 7 & H6B & Mediation & $\mathrm{SMS} \rightarrow \mathrm{eWOM} \rightarrow \mathrm{POS}$ & Significant & Accepted \\
\hline 8 & $\mathrm{H} 6 \mathrm{C}$ & Mediation & $\mathrm{MAP} \rightarrow \mathrm{eWOM} \rightarrow \mathrm{POS}$ & Significant & Accepted \\
\hline 9 & H6D & Mediation & $\mathrm{WSP} \rightarrow \mathrm{eWOM} \rightarrow \mathrm{POS}$ & Significant & Accepted \\
\hline 10 & H6E & Mediation & $\mathrm{ENT} \rightarrow \mathrm{eWOM} \rightarrow \mathrm{POS}$ & Significant & Accepted \\
\hline 11 & H7A & Mediation & $\mathrm{MMS} \rightarrow \mathrm{ATT} \rightarrow \mathrm{POS}$ & Significant & Accepted \\
\hline 12 & H7B & Mediation & $\mathrm{SMS} \rightarrow \mathrm{ATT} \rightarrow \mathrm{POS}$ & Significant & Accepted \\
\hline 13 & $\mathrm{H} 7 \mathrm{C}$ & Mediation & $\mathrm{MAP} \rightarrow \mathrm{ATT} \rightarrow \mathrm{POS}$ & Significant & Accepted \\
\hline 14 & H7D & Mediation & $\mathrm{WSP} \rightarrow \mathrm{ATT} \rightarrow \mathrm{POS}$ & Significant & Accepted \\
\hline 15 & H7E & Mediation & $\mathrm{ENT} \rightarrow \mathrm{ATT} \rightarrow \mathrm{POS}$ & Significant & Accepted \\
\hline 16 & H8A & Moderation & $\mathrm{MMS} \rightarrow \mathrm{TEC} \rightarrow \mathrm{POS}$ & Significant & Accepted \\
\hline 17 & H8B & Moderation & $\mathrm{SMS} \rightarrow \mathrm{TEC} \rightarrow \mathrm{POS}$ & Significant & Accepted \\
\hline 18 & $\mathrm{H} 8 \mathrm{C}$ & Moderation & $\mathrm{MAP} \rightarrow \mathrm{TEC} \rightarrow \mathrm{POS}$ & Significant & Accepted \\
\hline 19 & H8D & Moderation & $\mathrm{WSP} \rightarrow \mathrm{TEC} \rightarrow \mathrm{POS}$ & Significant & Accepted \\
\hline 20 & H8E & Moderation & $\mathrm{ENT} \rightarrow \mathrm{TEC} \rightarrow \mathrm{POS}$ & Significant & Accepted \\
\hline 21 & H9A & Moderation & $\mathrm{MMS} \rightarrow \mathrm{ADD} \rightarrow \mathrm{POS}$ & Significant & Accepted \\
\hline 22 & H9B & Moderation & $\mathrm{SMS} \rightarrow \mathrm{ADD} \rightarrow \mathrm{POS}$ & Significant & Accepted \\
\hline 23 & $\mathrm{H} 9 \mathrm{C}$ & Moderation & $\mathrm{MAP} \rightarrow \mathrm{ADD} \rightarrow \mathrm{POS}$ & Significant & Accepted \\
\hline 24 & H9D & Moderation & $\mathrm{WSP} \rightarrow \mathrm{ADD} \rightarrow \mathrm{POS}$ & Significant & Accepted \\
\hline 25 & H9E & Moderation & $\mathrm{ENT} \rightarrow \mathrm{ADD} \rightarrow \mathrm{POS}$ & Significant & Accepted \\
\hline
\end{tabular}

\section{Discussion}

The results of the undertaken study demonstrate the smartphone affirmative influence on student academic performance in universities; the previous literature also exhibited similar outcomes [25-29]. Outcomes also demonstrating that the multimedia media messaging (MMS) has an affirmative influence on student academic performance in universities, this also confirms the results of research studies that were carried out by Hasan et al. [15], Dzamesi et al. [16], Lepp et al. [29], Rosen et al. [31], and Junco [34]. Outcomes of the undertaken study further exhibit that smartphones' applications also exerted an affirmative influence on student academic performance in university students. These outcomes are consistent with the previous literature $[40,41,54,55]$. Findings of this research further demonstrate that warp-speed processing also has an affirmative influence on student academic performance of university students; similarly, Han and Yi [4], Shahibi and Aziz [23], Boahene et al. [24], and Chou and Liu [63] demonstrated similar outcomes. However, entertainment from the smartphone is a greater factor that hampers the university students' academic performance; previous literature also exhibited similar 
outcomes $[7,8,21,22,34]$. The outcomes of mediation exhibited that eWOM has an affirmative and cogent influence between smartphone functions on student academic performance in universities as the outcome variable [12,42]. Previous literature also demonstrated similar results [10,17,76-79]. The results of this research further exhibit that attitude exerts an affirmative and significant influence between functions of smartphone and university students' academic performance, which shows similar findings of previous literature [16,42,106-108]. Outcomes of moderation of addiction exhibit the significant influence between functions of smartphone and students' academic performance in universities as the outcome variable $[8,10,12,16,18,33]$. Finally, the moderating variable such as technology plays a significant influence between functions of smartphone and university students' academic performance, previous literature also exhibited similar outcomes such as García-Martínez et al. [14], Qi [25], Hossain et al. [26], Chen and Chang [90], Saroha and Diwan [91], Rout and Samarpita [92], McGill and Klobas [96], and Aljomaa et al. [97].

\section{Conclusions}

The objective of the undertaken study is to examine the influence of smartphone usage in university students, and its impact on their academic performance. This research study is exclusive in a way that the outcomes conclude that functions of the smartphone such as smartphone applications, multimedia service message (MMS), short service message (SMS), and warp-speed processing have an affirmative impact on student academic performance in universities as the outcome variable. However, the entertainment damages students' academic performance in universities. Similarly, the mediating variables such as electronic word of mouth (eWOM) and attitude have a significant and positive influence in a relationship between smartphone functions such as smartphone applications, multimedia service message (MMS), short service message (SMS), warp-speed processing, and entertainment, and student academic performance in universities in the case of Pakistani universities. The outcomes of moderation conclude that addiction and technology play a significant role as moderator in a relationship between smartphone functions such as smartphone applications, multimedia service message (MMS), short service message (SMS), warp-speed processing, and entertainment, and student academic performance in universities as the outcome variable. Hence, in conclusion, the outcomes demonstrate that smartphones influence student academic performance in universities in several ways. The previous literature demonstrated the mix results that there is an adverse or affirmative influence of smartphones on student academic performance; however, this study shows an affirmative and vital influence of smartphones on student academic performance of Pakistani university students. Thus, the outcomes of the undertaken study are important in a way that we used diverse functions of a smartphone and then evaluated the individual influence of these functions on the students' performance. Moreover, the results are significant because besides the exogenous variables, we also incorporated attitude and eWOM as a mediator, and technology and addiction as a moderator, to evaluate the impact of functions of the smartphone on student academic performance in universities as the outcome variable. The outcomes have concluded that these mediators and moderators have a significant influence between smartphone usage and academic performance of university students. Thus, the outcomes of this research enlighten the influence of multiple factors of the smartphone, and its influence on student academic performance in universities. Hence, this research has significant theoretical and practical implications.

\section{The Theoretical and Managerial Contribution}

The undertaken research laid down the basic foundations for future researchers to advance their studies concerning the influence of smartphones on student academic performance in universities as the outcome variable. The undertaken study provides a unique conceptual framework and measuring scales for different constructs. This research will also help future research scholars to replicate the outcomes of the undertaken study to another technology-related product, which can influence student academic performance in universities as the outcome variable, moreover, the outcomes of the 
undertaken study also provide guidelines to teachers, parents, and policymakers on how smartphones could be used in an effective way that transforms the maximum benefits regarding the best student academic performance in universities as the outcome variable. Towards student academic performance in universities, finally, this research also gives many directions to marketers and R\&D professionals of smartphone companies, the results also provide guidelines to marketers on how they can enhance the functionalities and sales of their smartphones. Marketers can use the functions of smartphones for the effective advertising of their services and products. Digital marketing is the new era of marketing, thus, the smartphone would be the best channel for the advertising of their brands. A mostly young population uses the smartphone, thus, this is an excellent opportunity to grasp this major segment of the population for optimal sales and branding.

\section{Limitations and Areas of Future Research Studies}

The undertaken research is significant in the field of smartphone functions and the student academic performance for university students. However, there are certain limitations of this research. The undertaken research is limited to certain cities and countries, for more generalized results, the sample data may be taken across countries of the region. For more robust results, data might be taken from rural and urban centers of the country. In this research, only a few mediating and moderating variables have been incorporated, thus, for future studies, several other psychological and behavioral variables might be included for more comprehensive outcomes. We used the SEM-based multivariate approach which does not address the cause and effect between the variables, therefore, in future research studies, more robust models could be employed for cause and effect investigation amongst the variables.

Author Contributions: Conceptualization, R.R.A. and F.S.; methodology, R.R.A.; software, R.H.S.; validation, D.S., R.R.A., and S.A.M.; formal analysis, R.R.A.; investigation, F.S.; resources, M.H.P.; data curation, R.H.S.; writing—original draft preparation, R.R.A., and F.S.; writing—review and editing, S.A.M.; visualization, D.S.; supervision, R.R.A.; project administration, M.H.P. All authors have read and agreed to the published version of the manuscript.

Funding: This research received no external funding.

Acknowledgments: We acknowledge the support of Indus University that provided during this project including administrative and technical support.

Conflicts of Interest: The authors declare no conflict of interest.

\section{References}

1. Deloitte Global Mobile Consumer Survey: US Edition. A New Era in Mobile Continues; Touche Tohmatsu Limited: London, UK, 2018; pp. 2-16. Available online: https:/www2.deloitte.com/content/dam/Deloitte/us/Docume nts/technology-media-telecommunications/us-tmt-global-mobile-consumer-survey-exec-summary-2018 .pdf (accessed on 11 July 2019).

2. Tindell, D.R.; Bohlander, R.W. The Use and Abuse of Cell Phones and Text Messaging in the Classroom: A Survey of College Students. Coll. Teach. 2012, 60,1-9. [CrossRef]

3. Ravizza, S.M.; Hambrick, D.Z.; Fenn, K.M. Non-academic Internet use in the classroom is negatively related to classroom learning regardless of intellectual ability. Comput. Educ. 2014, 78, 109-114. [CrossRef]

4. Han, S.; Yi, Y.J. How does the smartphone usage of college students affect academic performance? J. Comput. Assist. Learn. 2019, 35, 13-22. [CrossRef]

5. Al-Khalifa, H.S.; Garcia, R.A. The State of Social Media in Saudi Arabia's Higher Education. Int. J. Technol. Educ. Mark. 2013, 3, 65-76. [CrossRef]

6. Mendoza, J.S.; Pody, B.C.; Lee, S.; Kim, M.; McDonough, I.M. The effect of cellphones on attention and learning: The influences of time, distraction, and monophobia. Comput. Hum. Behav. 2018, 86, 52-60. [CrossRef]

7. Giunchiglia, F.; Zeni, M.; Gobbi, E.; Bignotti, E.; Bison, I. Mobile social media usage and academic performance. Comput. Hum. Behav. 2018, 82, 177-185. [CrossRef] 
8. Duke, É.; Montag, C. Smartphone addiction, daily interruptions and self-reported productivity. Addict. Behav. Rep. 2017, 6, 90-95. [CrossRef]

9. Yang, Z.; Asbury, K.; Griffiths, M.D. An exploration of problematic smartphone use among Chinese university students: Associations with academic anxiety, academic procrastination, self-regulation, and subjective wellbeing. Int. J. Ment. Health Addict. 2019, 17, 596-614. [CrossRef]

10. Nayak, J.K. Relationship among smartphone usage, addiction, academic performance and the moderating role of gender: A study of higher education students in India. Comput. Educ. 2018, 123, 164-173. [CrossRef]

11. Ali, H.H.; Imran, M.; Noori, Y. Frequency of Smart Phone Usage in Medical Students and its Association with Academic Performance. Int. J. Endorsing Health Sci. Res. 2019, 7, 154-161. [CrossRef]

12. Kibona, L.; Mgaya, G. Smartphones' effects on academic performance of higher learning students. A case of Ruaha Catholic University-Iringa, Tanzania. J. Multidiscip. Eng. Sci. Technol. 2015, 2, 777-784.

13. Froese, A.D.; Carpenter, C.N.; Inman, D.A.; Schooley, J.R.; Barnes, R.B.; Brecht, P.W.; Chacon, J.D. Effects of classroom cell phone use on expected and actual learning. Coll. Stud. J. 2012, 46, 323-332.

14. García-Martínez, I.; Fernández-Batanero, J.M.; Cobos Sanchiz, D.; Luque de la Rosa, A. Using Mobile Devices for Improving Learning Outcomes and Teachers' Professionalization. Sustainability 2019, 11, 6917. [CrossRef]

15. Hasan, R.; Palaniappan, S.; Mahmood, S.; Shah, B.; Abbas, A.; Sarker, K.U. Enhancing the Teaching and Learning Process Using Video Streaming Servers and Forecasting Techniques. Sustainability 2019, 11, 2049. [CrossRef]

16. Dzamesi, J.Y.W.; Akyina, K.O.; Manu, J.; Danso, E. Perceived Effects of Smartphone Usage on Students' Attitude Towards Learning in a Health Institution. J. Educ. Pract. 2019, 10, 71-81. [CrossRef]

17. Shields, S.D.; Riley, C.W. Examining the Correlation between Excessive Recreational Smartphone Use and Academic Performance Outcomes. J. High. Educ. Theory Pract. 2019, 19. [CrossRef]

18. Choi, S. Relationships between Smartphone Usage, Sleep Patterns and Nursing Students' Learning Engagement. J. Korean Biol. Nurs. Sci. 2019, 21, 231-238. [CrossRef]

19. Calafell, G.; Banqué, N.; Viciana, S. Purchase and Use of New Technologies among Young People: Guidelines for Sustainable Consumption Education. Sustainability 2019, 11, 1541. [CrossRef]

20. Molina-Carmona, R.; Pertegal-Felices, M.L.; Jimeno-Morenilla, A.; Mora-Mora, H. Virtual Reality Learning Activities for Multimedia Students to Enhance Spatial Ability. Sustainability 2018, 10, 1074. [CrossRef]

21. Schaal, S.; Lude, A. Using Mobile Devices in Environmental Education and Education for Sustainable Development-Comparing Theory and Practice in a Nation-Wide Survey. Sustainability 2015, 7, 10153-10170. [CrossRef]

22. Han, S.; Capraro, R.M.; Capraro, M.M. How science, technology, engineering, and mathematics project based learning affects high-need students in the US. Learn. Indiv. Diff. 2016, 51, 157-166. [CrossRef]

23. Shahibi, M.S.; Aziz, F.A. The Effect of Smartphone that Influences the Compulsive Usage among Students. Int. J. Acad. Res. Bus. Soc. 2017, 7, 808-908. [CrossRef]

24. Boahene, K.O.; Fang, J.; Sampong, F. Social Media Usage, and Tertiary Students' Academic Performance: Examining the Influences of Academic Self-Efficacy and Innovation Characteristics. Sustainability 2019, 11, 2431. [CrossRef]

25. Qi, C. A double-edged sword? Exploring the impact of students' academic usage of mobile devices on technostress and academic performance. Behav. Inf. Technol. 2019, 38, 1337-1354. [CrossRef]

26. Hossain, S.F.A.; Nurunnabi, M.; Hussain, K.; Saha, S.K. Effects of variety-seeking intention by mobile phone usage on university students' academic performance. Cogent Educ. 2019, 6. [CrossRef]

27. Jacobsen, W.C.; Forste, R. The wired generation: Academic and social outcomes of electronic media use among university students. Cyberpsychol. Behav. Soc. Netw. 2011, 14, 275-280. [CrossRef]

28. Hong, F.Y.; Chiu, S.I.; Huang, D.H. A model of the relationship between psychological characteristics, mobile phone addiction and use of mobile phones by Taiwanese university female students. Comput. Hum. Behav. 2012, 28, 2152-2159. [CrossRef]

29. Lepp, A.; Barkley, J.E.; Karpinski, A.C. The relationship between cell phone use, academic performance, anxiety, and satisfaction with life in college students. Comput. Hum. Behav. 2014, 31, 343-350. [CrossRef]

30. Wood, E.; Zivcakova, L.; Gentile, P.; Archer, K.; De Pasquale, D.; Nosko, A. Examining the impact of off-task multi-tasking with technology on real-time classroom learning. Comput. Educ. 2012, 58, 365-374. [CrossRef] 
31. Rosen, L.D.; Lim, A.F.; Carrier, L.M.; Cheever, N.A. An empirical examination of the educational impact of text message-induced task switching in the classroom: Educational implications and strategies to enhance learning. Psicol. Educ. 2011, 17, 163-177.

32. Kirschner, P.A.; Karpinski, A.C. Facebook, and academic performance. Comput. Hum. Behav. 2010, 26, 1237-1245. [CrossRef]

33. Karpinski, A.; Kirschner, P.; Ozer, I.; Mellott, J.; Ochwo, P. An exploration of social networking site use, multitasking, and academic performance between the United States and European university students. Comput. Hum. Behav. 2013, 29, 1182-1192. [CrossRef]

34. Junco, R. In-class multitasking and academic performance. Comput. Hum. Behav. 2012, 28, 2236-2243. [CrossRef]

35. Ahmed, R.R.; Streimikiene, D.; Berchtold, G.; Vveinhardt, J.; Channar, Z.A.; Soomro, R.H. Effectiveness of Online Digital Media Advertising as A Strategic Tool for Building Brand Sustainability: Evidence from FMCGs and Services Sectors of Pakistan. Sustainability 2019, 11, 3436. [CrossRef]

36. Bellman, S.; Potter, R.F.; Treleaven-Hassard, S.; Robinson, J.A.; Varan, D. The Effectiveness of Branded Mobile Phone Apps. J. Interact. Mark. 2011, 25, 191-200. [CrossRef]

37. Confos, N.; Davis, T. Young consumer-brand relationship-building potential using digital marketing. Eur. J. Mark. 2016, 50, 1993-2017. [CrossRef]

38. Handayanto, A.J. Analysis of Consumer Awareness on Twitter Communication and Brand Equity of Bear Brand Milk. J. Res. Mark. 2016, 5, 348-356. [CrossRef]

39. Mathwick, C.; Wiertz, C.; De Ruyter, K. Social Capital Production in a Virtual P3 Community. J. Consum. Res. 2008, 34, 832-849. [CrossRef]

40. Woodcock, B.; Middleton, A.; Nortcliffe, A. Considering the smartphone learner: An investigation into student interest in the use of personal technology to enhance their learning. Stud. Engagem. Exp. J. 2012, 1, 1-15.

41. Al-Meshal, S.; Almotairi, M. Consumer Acceptance of Mobile Marketing: An Empirical Study on the Saudi Female. Int. J. Mark. Stud. 2013, 5, 94-100. [CrossRef]

42. Çizmeci, F.; Ercan, T. The Effect of Digital Marketing Communication Tools in the Creation of Brand Awareness by Housing Companies. Megaron 2015, 10, 149-161.

43. Muk, A. Consumers' intention to opt into SMS advertising. Int. J. Advert. 2007, 26, 177-198. [CrossRef]

44. Kolla, N. Consumer Attitude towards Mobile Advertising: An Empirical Study. Indian J. Appl. Res. 2011, 4, 340-342. [CrossRef]

45. Barwise, P.; Strong, C. Permission-based mobile advertising. J. Interact. Mark. 2002, 16, 14-24. [CrossRef]

46. Bamoriya, P.; Bamoriya, H.; Singh, P. Perceptual mapping of electronic banking channels in India: A Multidimensional Scaling approach. Int. J. Res. Stud. Manag. 2014, 3, 17-26. [CrossRef]

47. Scharl, A.; Dickinger, A.; Murphy, J. Diffusion and success factors of mobile marketing. Electron. Commer. Res. Appl. 2005, 4, 159-173. [CrossRef]

48. Kenny, D.; Marshall, J.F. Contextual marketing: The real business of the Internet. Harv. Bus. Rev. 2000, 78, 119-125.

49. Yuan, S.T.; Tsao, Y.W. A recommendation mechanism for contextualized mobile advertising. Expert Syst. Appl. 2003, 24, 399-414. [CrossRef]

50. Barnes, T. RSS: Marketing newest communication channel. J. Website Promot. 2007, 1, 15-30. [CrossRef]

51. Kaplan, A.M.; Haenlein, M. Users of the world, unite! The challenges and opportunities of social media. Bus. Horiz. 2010, 53, 59-68. [CrossRef]

52. Saura, J.R.; Palos-Sánchez, P.; Cerdá Suárez, L.M. Understanding the digital marketing environment with KPIs and web analytics. Future Internet 2017, 9, 76. [CrossRef]

53. Ross, C.; Orr, E.S.; Sisic, M.; Arseneault, J.M.; Simmering, M.G.; Orr, R.R. Personality and motivations associated with Facebook use. Comput. Hum. Behav. 2009, 25, 578-586. [CrossRef]

54. Kumar, M. Impact of the evolution of smartphones in education technology and its application in technical and professional studies: An Indian perspective. Int. J. Manag. Inf. Technol. 2011, 3, 39-49.

55. Mtega, W.P.; Bernard, R.; Msungu, A.C.; Sanare, R. Using mobile phones for teaching and learning purposes in higher learning institutions: The case of Sokoine University of Agriculture in Tanzania. In Proceedings of the 5th UbuntuNet Alliance Annual Conference, Dar es Salam, Tanzania, 14-16 November 2012; pp. 118-129. Available online: https://repository.ubuntunet.net/handle/10.20374/130 (accessed on 25 June 2019). 
56. Montgomery, K.C.; Chester, J. Interactive Food and Beverage Marketing: Targeting Adolescents in the Digital Age. J. Adolesc. Health 2009, 45, S18-S29. [CrossRef] [PubMed]

57. Chaffey, D. E-Business and E Commerce Management, 3rd ed.; Prentice-Hall: Alexandria, VA, USA, 2008.

58. Chi, H. Interactive Digital Advertising vs. Virtual Brand Community: Exploratory Study of User Motivation and Social Media Marketing Responses in Taiwan. J. Interact. Advert. 2011, 12, 44-61. [CrossRef]

59. Holzer, A.; Ondrus, J. Trends in mobile application development. In Lecture Notes of the Institute for Computer Sciences, Social Informatics and Telecommunications Engineering; Springer: Berlin/Heidelberg, Germany, 2009; pp. 55-64.

60. Munsell, C.R.; Harris, J.L.; Sarda, V.; Schwartz, M.B. Parents' beliefs about the health fullness of sugary drink options: Opportunities to address misperceptions. Public Health Nutr. 2015, 19, 46-54. [CrossRef]

61. Bu, N.; Niu, S.; Yu, L.; Ma, W.; Long, G. Bridging Semantic Gap between App Names: Collective Matrix Factorization for Similar Mobile App Recommendation. In Lecture Notes in Computer Science; Springer: Berlin/Heidelberg, Germany, 2016; pp. 324-339.

62. Mady, T.T. Sentiment toward marketing: Should we care about consumer alienation and readiness to use technology? J. Consum. Behav. 2011, 10, 192-204. [CrossRef]

63. Chou, S.W.; Liu, C.H. Learning effectiveness in a Web-based virtual learning environment: A learner control perspective. J. Comput. Assist. Learn. 2005, 21, 65-76. [CrossRef]

64. Bush, A.J.; Bush, V.; Harris, S. Advertiser perceptions of the Internet as a marketing communications tool. J. Advert. Res. 1998, 38, 17-27.

65. Jobe, W. Native Apps vs. Mobile Web Apps. Int. J. Interact. Mob. Technol. 2013, 7, 27. [CrossRef]

66. Lulu, D.L.B.; Kuflik, T. Wise Mobile Icons Organization: Apps Taxonomy Classification Using Functionality Mining to Ease Apps Finding. Mob. Inf. Syst. 2016, 2016, 3083450.

67. Lui, K.; Wong, A. Does media multitasking always hurt? A positive correlation between multitasking and multisensory integration. Psychon. Bull. Rev. 2012, 19, 647-653. [CrossRef] [PubMed]

68. Prabu, D.; Kim, J.; Brickman, J.; Ran, W.; Curtis, C. Mobile phone distraction while studying. New Media Soc. 2014. [CrossRef]

69. Mangold, W.G.; Faulds, D.J. Social media: The new hybrid element of the promotion mix. Bus. Horiz. 2009, 52, 357-365. [CrossRef]

70. Laroche, M.; Habibi, M.R.; Richard, M.O.; Sankaranarayanan, R. The effects of social media-based brand communities on brand community markers, value creation practices, brands trust and brand loyalty. Comput. Hum. Behav. 2012, 28, 1755-1767. [CrossRef]

71. Blair, M.K. Using Digital and Social Media Platforms for Social Marketing; Oxford Medicine Online; Oxford University Press: Oxford, UK, 2017.

72. Li, X.; Chan, K.W.; Kim, S. Service with Emoticons: How Customers Interpret Employee Use of Emoticons in Online Service Encounters. J. Consum. Res. 2019, 45, 973-987. [CrossRef]

73. Palos-Sanchez, P.; Saura, J.R.; Martin-Velicia, F. A study of the effects of programmatic advertising on users' concerns about privacy overtime. J. Bus. Res. 2019, 96, 61-72. [CrossRef]

74. Kim, K.; Stout, P.A.; Yoo, C.Y. Assessing the effects of animation in online banner advertising: Hierarchy of effects model. J. Interact. Advert. 2004, 4, 49-60.

75. Popp, B.; Woratschek, H. consumer-brand identification revisited: An integrative framework of brand identification, customer satisfaction, and price image and their role for brand loyalty and word of mouth. J. Brand Manag. 2017, 24, 1-21. [CrossRef]

76. Lien, C.H.; Cao, Y. Examining wechat users' motivations, trust, attitudes, and positive word-of-mouth: Evidence from china. Comput. Hum. Behav. 2014, 41, 104-111. [CrossRef]

77. Schmäh, M.; Wilke, T.; Rossmann, A. Electronic Word-of-Mouth: A Systematic Literature Analysis. In Digital Enterprise Computing; Rossmann, A., Zimmermann, A., Eds.; Gesellschaft für Informatik: Bonn, Germany, 2017; pp. 147-158.

78. Hennig-Thurau, T.; Malthouse, E.C.; Friege, C.; Gensler, S.; Lobschat, L.; Rangaswamy, A.; Skiera, B. The impact of new media on customer relationships. J. Serv. Res. 2010, 13, 311-330. [CrossRef]

79. Ellison, N.B.; Lampe, C.; Steinfield, C. Spatially Bounded Online Social Networks and Social Capital: The Role of Facebook. In Proceedings of the Annual Conference of the International Communication Association (ICA), Dresden, Germany, 19-23 June 2006. 
80. Herr, P.M.; Kardes, F.R.; Kim, J. Effects of word-of-mouth and product-attribute information on persuasion: An accessibility-diagnosticity perspective. J. Consum. Res. 1991, 17, 454-462. [CrossRef]

81. Virvilaite, R.; Tumasonyte, D.; Sliburyte, L. The influence of word of mouth communication on brand equity: Receiver perspectives. Procedia Soc. Behav. Sci. 2015, 213, 641-646. [CrossRef]

82. Cornelissen, J. Corporate image: An audience centered model. Corp. Commun. Int. J. 2000, 5, 119-125. [CrossRef]

83. Vermeulen, I.E.; Seegers, D. Tried and tested: The impact of online hotel reviews on consumer consideration. Tour. Manag. 2009, 30, 123-127. [CrossRef]

84. Morgan, N.J.; Pritchard, A.; Piggott, R. Destination branding and the role of the stakeholders: The case of New Zealand. J. Vacat. Mark. 2003, 9, 285-299. [CrossRef]

85. Goldenberg, J.; Libai, B.; Muller, E. Talk of the network: A complex systems look at the underlying process of word-of-mouth. Mark. Lett. 2001, 12, 211-223. [CrossRef]

86. Yang, H.P.; Mutum, D.S. Electronic word-of-mouth for university selection: Implications for academic leaders and recruitment managers. J. Gen. Manag. 2015, 40, 23-44. [CrossRef]

87. Wang, Y.; Sun, S. Assessing beliefs, attitudes, and behavioral responses toward online advertising in three countries. Int. Bus. Rev. 2010, 19, 333-344. [CrossRef]

88. Zhang, J.; Mao, E. From Online Motivations to Ad Clicks and to Behavioral Intentions: An Empirical Study of Consumer Response to Social Media Advertising. Psychol. Mark. 2016, 33, 155-164. [CrossRef]

89. Jabali, O.; Saeedi, M.; Shbeitah, G.; Ayyoub, A.A. Medical faculty members' perception of smartphones as an educational tool. BMC Med. Educ. 2019, 19, 264. [CrossRef] [PubMed]

90. Chen, T.Y.; Chang, H.S. Reducing consumers' perceived risk through banking service quality cues in Taiwan. J. Bus. Psychol. 2005, 19, 521-539. [CrossRef]

91. Saroha, R.; Diwan, S.P. Modelling customer satisfaction and customer loyalty in the frame of the telecommunications industry: A review. EuroMed J. Manag. 2017, 2, 15-37. [CrossRef]

92. Rout, B.; Samarpita, S. Technology of e-banking: Customer perception and satisfaction towards public sector banks in Bhubaneswar city. IOSR J. Bus. Manag. 2017, 19, 29-38. [CrossRef]

93. Prasadh, R.R.; Suresh, J. Customer satisfaction index model for the Indian banking industry: A qualitative study. Asian Soc. Sci. 2016, 13, 114-129. [CrossRef]

94. Raza, S.A.; Hanif, N. Factors acting internet banking adoption among internal and external customers: A case of Pakistan. Int. J. Electron. Financ. 2013, 7, 82-96. [CrossRef]

95. Angur, M.G.; Nataraajan, R.; Jahera, J.S., Jr. Service quality in the banking industry: An assessment in a developing economy. Int. J. Bank Mark. 1999, 17, 116-125. [CrossRef]

96. McGill, T.J.; Klobas, J.E. A task-Technology fit view of learning management system impact. Comput. Educ. 2009, 52, 496-508. [CrossRef]

97. Aljomaa, S.S.; Qudah, M.F.A.; Albursan, I.S.; Bakhiet, S.F.; Abdul-Jabbar, A.S. Smartphone addiction among university students in the light of some variables. Comput. Hum. Behav. 2016, 61, 155-164. [CrossRef]

98. McCloskey, W. Retail. White Paper; Email Data Source: New York, NY, USA, 2006.

99. Ravizza, S.M.; Delgado, M.R. Motivational enhancement of cognitive control depends on depressive symptoms. Emotion 2014, 14, 646-650. [CrossRef]

100. Widyanto, L.; Griffiths, M. Internet addiction: Does it really exist? In Psychology and the Internet: Intrapersonal, Interpersonal, and Transpersonal Applications; Gackenbach, J., Ed.; Academic Press: Burlington, NJ, USA, 2006; pp. 141-163.

101. Van Deursen, A.J.; Bolle, C.L.; Hegner, S.M.; Kommers, P.A. Modeling habitual and addictive smartphone behavior: The role of smartphone usage types, emotional intelligence, social stress, self-regulation, age, and gender. Comput. Hum. Behav. 2015, 45, 411-420. [CrossRef]

102. Samaha, M.; Hawi, N. Relationships among smartphone addiction, stress, academic performance, and satisfaction with life. Comput. Hum. Behav. 2016, 57, 321-325. [CrossRef]

103. Gökçearslan, Ş.; Mumcu, F.K.; Haşlaman, T.; Çevik, Y.D. Modelling smartphone addiction: The role of smartphone usage, self-regulation, general self-efficacy and cyber loafing in university students. Comput. Hum. Behav. 2016, 63, 639-649. [CrossRef]

104. Wang, H.; Huang, H.; Wu, H.M. Relationship between personality and mobile phone addiction: A mediating role of social anxiety. Chin. J. Clin. Psychol. 2014, 3, 447-450.

105. Groeger, L.; Buttle, F. Deciphering Word-of-Mouth Marketing Campaign Reach: Every day Conversation Versus Institutionalized Word of Mouth. J. Advert. Res. 2016, 56, 368-384. [CrossRef] 
106. Ahmed, R.R.; Vveinhardt, J.; Štreimikiene, D.; Ashraf, M. Interactive Digital Media and Impact of Customer Attitude and Technology on Brand Awareness: Evidence from the South Asian Countries. J. Bus. Econ. Manag. 2017, 18, 1115-1134. [CrossRef]

107. Filipovic, J. Brand awareness and buying intention in the online environment. Marketing 2015, 46, $277-284$. [CrossRef]

108. Geçti, F.; Gümüs, N. Examining the Attitudes towards Mobile Advertising Messages: A Field Research on Turkish Consumers. China-USA Bus. Rev. 2013, 12, 204-210.

109. Ahmed, R.R.; Vveinhardt, J.; Streimikiene, D.; Awais, M. Mediating and Marketing factors influence the prescription behavior of Physicians: An Empirical Investigation. Amfiteatru Econ. 2016, 18, 153-167.

110. Ahmed, R.R.; Vveinhardt, J.; Streimikiene, D. The direct and indirect impact of the Pharmaceutical industry in Economic expansion and Job creation: Evidence from Bootstrapping and Normal theory methods. Amfiteatru Econ. 2018, 20, 454-469. [CrossRef]

111. Hair, J.F.; Black, W.C.; Babin, B.J.; Anderson, R.E. Multivariate Data Analysis, 7th ed.; Prentice-Hall: Upper Saddle River, NJ, USA, 2010.

112. Huang, J.H.; Lee, B.C.Y.; Ho, S.H. Consumer attitude toward grey market goods. Int. Mark. Rev. 2004, 21, 598-614. [CrossRef]

113. Byrne, B.M. Structural Equation Modeling with AMOS, Basic Concepts, Application, and Programming, 2nd ed.; La Erlbaum Associates: Hillsdale, NJ, USA, 2009. [CrossRef]

114. Fornell, C.; Larcker, D.F. Evaluating structural equation models with unobservable variables and measurement error. J. Mark. Res. 1981, 39, 39-50. [CrossRef]

115. Kline, T.J.B.; Sulsky, L.M.; Rever-Moriyama, S.D. Common method variance and specification errors: A practical approach to detection. J. Psychol. 2000, 134, 401-421. [CrossRef] [PubMed]

116. Emory, C.W.; Cooper, D.R. Business Research Methods, 4th ed.; Irvin: Boston, MA, USA, 1991.

117. Kaiser, H.F. An index of factorial simplicity. Psychometrika 1974, 39, 31-36. [CrossRef]

118. Hayes, A.F. Introduction to Mediation, Moderation, and Conditional Process Analysis: A Regression-Based Approach; The Guilford Press: New York, NY, USA, 2013. 